\title{
Muslim Cultures beyond the Aperture: An East African Photo-Story Illuminated by First-Hand Accounts
}

\author{
Nasira Sheikh-Miller \\ nasira.sheikhmiller@gmail.com
}

\begin{abstract}
This paper is an exploration of Indian Muslim culture in East Africa through pre- and postindependence eras via the medium of photography.

It examines the art and craft of photographic practice, the training of photographers, their social networks and those of their patrons, as well as the personal context of photographs. It also discusses the dispersal of archives and personal collections.

It is based upon first-hand accounts from professional photographers, their family members as well as patrons, whose ancestors travelled from India via Indian Ocean trade routes.

Fareh te chareh is a Gujarati proverb meaning 'A person who roams advances.'
\end{abstract}

Keywords

photography - photojournalism - diaspora - Kenya - Zanzibar - studio - colonial - Bohra

Dedicated to my parents; my late mother, Farida Sheikh and my father Noordin Sheikh

1

Introductory Background and Context

This paper is based on fieldwork drawing upon first-hand accounts from professional photographers, their family members as well as patrons of photography discussing their photographic collections (please see Table 1). These individuals were part of the South Asian diaspora to East Africa whose ancestors travelled from India via the Indian Ocean trade routes, and for the most part from the nineteenth century onward. 


\section{Interviewees}

Late Shirin Adamjee, d. 2017 (Muslim heritage) Shirin's father established a small studio in a corrugated hut in the Tanzanian town of Korogwe. She began working in the business as a young girl before becoming a studio photographer herself in Nairobi. Salim Amin (Muslim heritage)

Salim is the son of Kenyan photojournalist and author Mohamed Amin. Mo, who died in 1996, was known for his coverage of the fall from power of Idi Amin, as well as the Ethiopian famine in 1984. Salim now runs his father's media company, Camerapix, and is the Chairman and Founder of the Mohamed Amin Foundation.

Mohinder Dhillon (Sikh heritage)

Mohinder founded Africapix Media Ltd. He spent many years working as a photojournalist and he was Haile Selassie's personal photographer. He retired following a helicopter crash at the age of 71.

Anisah Ebrahimjee (Muslim heritage)

Anisah is the former Chairman of the New

Generation Council of the Karimjee Jivanjee family.

She has kindly provided photographs from both her maternal (Karimjee Jivanjee) and paternal (Ebrahimjee) family collections.

Hamida Essajee (Muslim heritage)

Hamida grew up in Mombasa in the 1940s and 50 os and was a regular user of the well-known local photo studio run by N.V. Parekh.

Bhaju Bhai Patel (Hindu heritage)

Bachu's father founded Vanguard Studios in Nairobi in the 193os. Bachu now runs Vanguard, but it has moved away from its roots in photography.

Zarina Patel (Muslim heritage)

Zarina is a writer and academic who has published several books and articles focusing on Asians in East Africa. She is also an Editorial Director of Awaaz Magazine. Zarina's grandfather was Alibhai Mulla Jeevanjee, a philanthropist and anti-colonial activist. Noordin Patwa (Muslim heritage) and Pomi Bahal (Hindu heritage)

Noordin used to run the anti-colonial Citizen Times newspaper. The work of local photojournalists such as Priya Ramrakha was regularly found in this publication. Pomi is an amateur photographer with a great interest in the Asian community in East Africa.

\section{Dates Relevant photographs}

July $2012 \quad$ Figs. 2, 23-24 and 27.

and

November

2016

July 2012

Figs. 3, 5, and 28-34.
TABLE 1

First-hand accounts from photographers, their family members and patrons

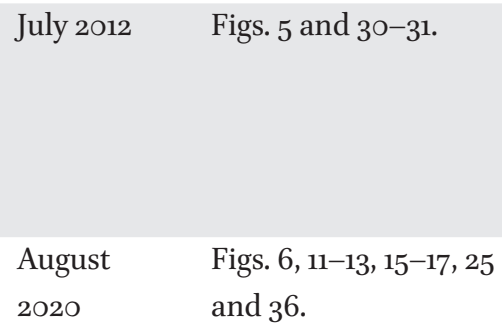

August Figs. 6, 11-13, 15-17, 25
$2020 \quad$ and 36 .
July 2012
Figs. 18-19.

July 2012 
TABLE 1

First-hand accounts from photographers, their family members and patrons (cont.)

\section{Interviewees}

Dates

Relevant photographs

Masud Quraishy (Muslim heritage)

July 2012

Masud has been a wildlife photographer for over 50 years. He has had his work exhibited in many cities around the world including Nairobi, London, Toronto and Miami.

Fatima Sadikot (Muslim heritage)

Fatima is the granddaughter of Tayabali Hassanali Adamjee, a photographer working in Zanzibar in the 1920s. Tayabali's son, Abid, also became a photographer and the family studio closed, upon his death, in 1998.

Asif Sheikh (Muslim heritage)

Asif is the CEO and Founder of Africa 24 Media, a pan

African TV content producer and the developer of the үево factual video on demand service. Asif has also kindly provided a couple of photographs from his personal family archive.

Noordin Sheikh with late Akbar Taherali (both

Muslim heritage)

Noordin Sheikh and Akbar Taherali were childhood friends in Mombasa who both moved to Nairobi for career opportunities. They were regular visitors to studios. Noordin's late wife Farida Sheikh was a recipient of a Karimjee Jivanjee scholarship.

John Sibi-Okumu (Christian heritage)

John is a Kenyan writer, teacher and actor. He is also a director of Awaaz Magazine. John's play "Role Play" focuses on communal relations following the coup of 1982. John discussed his own experience of using local photo studios.

Muzu Sulemanji (Muslim heritage)

Muzu was born in Zanzibar and now lives in Dar es Salaam where he is an established photographer and artist. Muzu uses photographs as a basis for his paintings. He also runs the ART n' FRAME gallery in the city. He has been exhibiting since the 199os.

Nazir Sulemanji (Muslim heritage)

Nazir is the brother of Muzu and was himself a former photojournalist and studio photographer in Dar es Salaam. He set up his own studio, Color Centre, which is run by his brothers Muzu and Salim. In recent years, Nazir moved to the UK and worked for Kodak. Chandoo Vasani (Hindu heritage)

Chandoo's father founded a photo studio in Thika, Kenya, in the 193os. Chandoo worked in the studio and eventually became a photojournalist himself. He worked for the East African Standard before moving into advertising. All three of his brothers went into photography related careers. April $2012 \quad$ Figs. 36-38.

\section{May 2012}

Figs. 1, 7-10 and 14-15. and August

2020

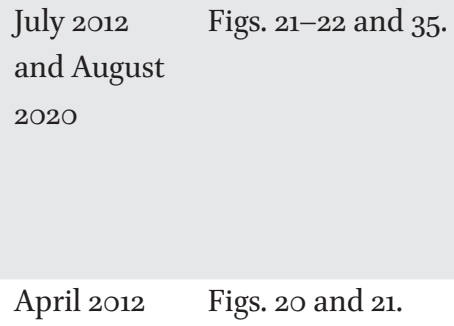

Figs. $18-19$ and 22-23. 


\begin{tabular}{|c|c|c|}
\hline Interviewees & Dates & Relevant photographs \\
\hline $\begin{array}{l}\text { Anil Vidyarthi (Hindu heritage) } \\
\text { Anil was previously a global photojournalist. He } \\
\text { moved into the printing industry in the 197os. He was } \\
\text { a cousin of the photojournalist Priya Ramrakha who } \\
\text { was killed in an ambush in Nigeria in } 1968 .\end{array}$ & July 2012 & Figs. $3,5,29-32$. \\
\hline $\begin{array}{l}\text { Duncan Willets (Christian heritage) } \\
\text { Duncan has been a photojournalist for many years } \\
\text { and was a former colleague and partner of the late } \\
\text { Mohamed Amin, publishing many works together } \\
\text { over the course of a 20-year partnership. Duncan now } \\
\text { works with Mo Amin's son, Salim. }\end{array}$ & July 2012 & Figs. 3 and 29. \\
\hline
\end{tabular}

The essay explores the art and craft of photographic practise, the training and social networks of photographers and patrons, the personal and social context of photographs and the stories they reveal of Muslim cultures of Asian descent, living through pre- and post-independence eras in East Africa.

It is ultimately an exploration of Indian Muslim culture via an art form and in this case through the medium of photography.

A multidisciplinary approach shall endeavour to establish ideas and concepts, provide further insights into current thought, and offer a wide interpretation of material culture as well as depth and scope.

In order to probe the construct of photographic material further, accounts from and works of photographers from Muslim and non-Muslim descent are offered, either to provide further insights into photographic practise or to reflect the context of the diverse societies, Muslim cultures lived and worked within, in colonial and post-independent East Africa.

The genres of early and modernist studios, activist and documentary worlds of photography are undercurrent themes among the photography case studies, within the context of this research paper.

The paper will document and discuss the dispersal of archives, private patronage and personal collections, agency and activism and the significance of informal social networks determining training and education.

Some of the arguments presented draw upon discussions raised in an African arts article, which focused on the lives and works of Asian photojournalists and studio photographers from East Africa in the colonial and post-independence periods. ${ }^{1}$

The ideas, concepts and works depicted in this essay will furthermore aim to extend the total archive of African photography as well as to help challenge the problematic manner by which the term 'Africa' is understood, 'most of all,' as Haney has eloquently pronounced in her publication, Photography and Africa, 'for the way it is often substituted as a singular term, to stand for a multiplicity of cultural, political and artistic experiences. $^{2}$

\section{Colonial Era Photography}

The colonial government genre of photography promoted the strategic aims of European colonial governments, local elites, trade and economy. Societies were
TABLE 1

First-hand accounts from photographers, their family members and patrons (cont.) 
interpreted through the lens of the colonial government. Examples of 'type' photography and 'occupation' photography reduced people to ethnic stereotypes and definition by occupation. ${ }^{3}$

The genre of 'human/occupation type' photography objectified subject peoples, 'froze images of "primitive" people whom the universalizing and homogenizing tides of modernity were otherwise washing away." ${ }^{4}$ Tourist literature romanticized and categorized African communities. ${ }^{5}$ Haney, Landau and Pinney have discussed how photographers, white and non-white, itinerant and local, mass circulated such iconography of Africans and Asians in newspapers, books, postcards and travel albums (Haney, 2010, pp. 15-55 and 57-82; Landau, 2002, pp. 1-2 and 141-71; Pinney, 1997, pp. 17-71).

Early Indian photographers would take on assignments including ones that were part of the colonial era archive and some which catered primarily to Europeans, often published into postcards intended for European audiences and visitors. Some of the postcards were of the staged tableaux variety. Tableaux photography was in essence 'orientalist' photography. ${ }^{6}$ Actors would be paid to wear costumes and props provided to represent colonial subjects. In one of the postcards published in Early Postcards of Zanzibar by Evans ${ }^{7}$ - 'Arab Ladies, women are dressed up to depict Arab women. The scholar of literature Edward Said has written extensive expositions on romanticized notions of colonized subjects in Orientalism and its links to imperialist political systems. ${ }^{8}$

In a recent retrospective exhibition at the Hayward gallery in London, The Museum of Emotion, the artist Kader Attia has included examples of colonial era 'type' photography within an artwork exhibit from 2013, titled Measure and Control. In the accompanying label he elucidates, 'I'm critiquing those social sciences that claim to control and understand the world ... just by classifying it.' ${ }^{\text {. }}$

As a counter-point, this paper will attempt to emphasize stories about Muslim photographers and patrons, consider chronicling their migratory experiences from India to East Africa and amplify the communities they were, or are based in. The paper shall endeavour to go further than what writers Enwezor and Zaya describe as 'The visual fictions of the African Continent' (cited in Haney, 2010, pp. 6-12) and to provide compelling counter-narratives, going beyond enduring colonial archives, specifically, through the presentation of works and biographies of photographers and in some cases patrons, from areas bordering the Indian Ocean, such as Stone Town (Zanzibar), Dar es Salaam, Mombasa and going further inland, to Nairobi.

Particular attention will be given to studio photographers, Tayabali Hassanali Adamjee (1901-94, fig. 1) and Shirin Adamjee (d. 2017, fig. 2) as well as photojournalist Mohamed (Mo) Amin (1943-96, fig. 3). These case studies together with the works of other Muslim photographers and the visual culture of photographic archives, shall offer valuable perspectives, on the existences of Muslim cultures, along with their interaction with other cultures in East African societies of the Indian Ocean. The critical study of photography in East Africa, is particularly limited when compared to other regions, and though photographers such as Mo Amin are well known, his work has had limited scholarly gaze (Sheikh-Miller, 2015, pp. 38-9).

As well as chronicling migratory experiences from India to East Africa within scholarship, the paper shall provide a brief history of early studio photography in East Africa for context. 

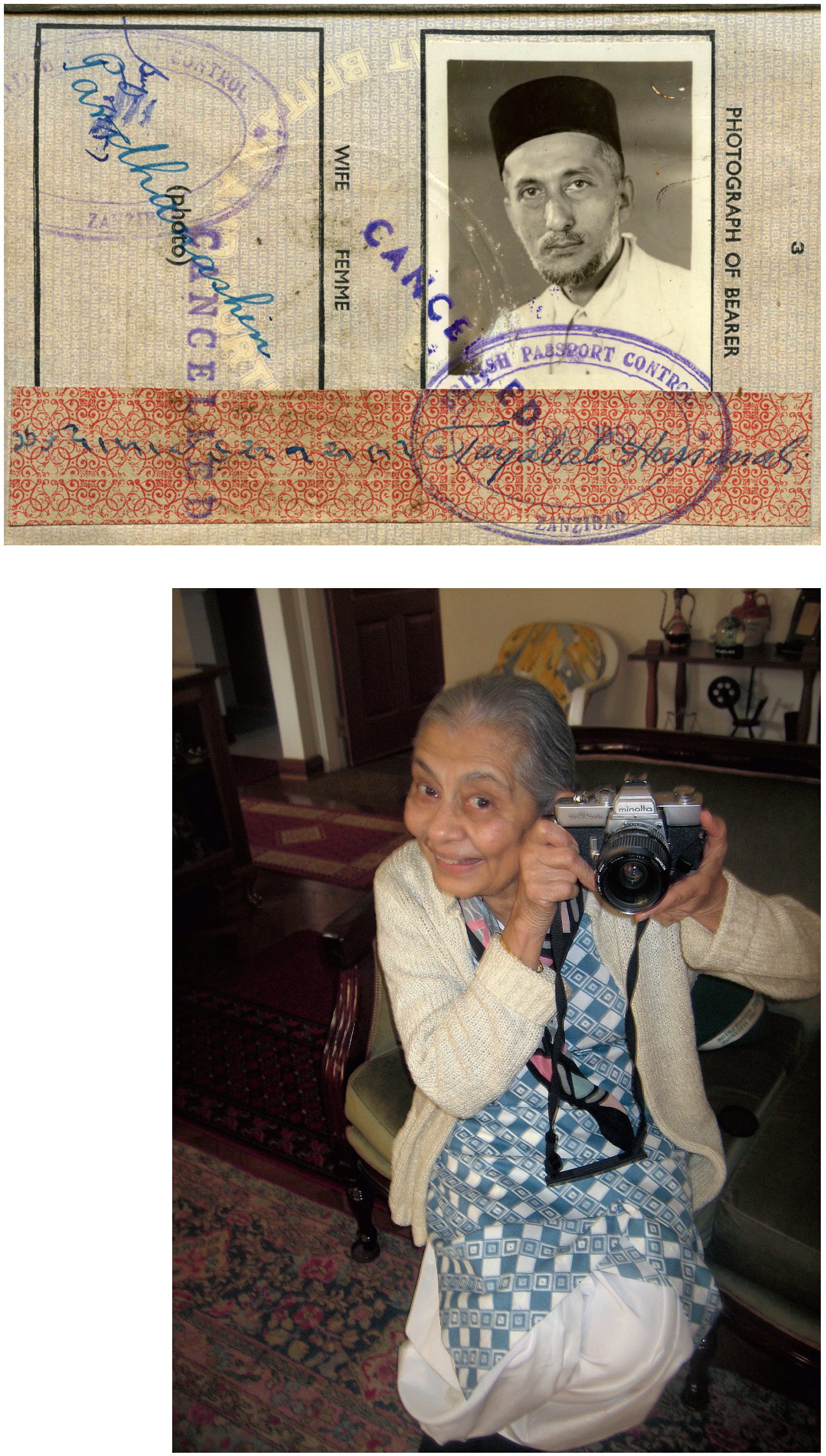

FIGURE 1

Passport photograph of Zanzibar studio photographer, Tayabali Hassanali Adamjee. Self-taught, he started his photographic career in his twenties, learning his skills from photographic text books. Passport photographer unknown COURTESY OF GRANDDAUGHTER, FATIMA SADIKOT'S PRIVATE COLLECTION

FIGURE 2

Female studio photographer Shirin Adamjee posing with her favourite Minolta analogue camera at her home in Nairobi, 2012. She closed her studio in 2007 after the digital revolution in photography.

PHOTOGRAPH TAKEN BY NASIRA SHEIKH-MILLER 
FIGURE 3

Photojournalist Mohamed (Mo) Amin (1943-1996) with his specially adapted prosthesis arm. Photograph by an unknown photographer. He lost his arm covering an assignment in Addis Ababa, Ethiopia, in 1991. Photographer unknown PHOTOGRAPH COURTESY OF SALIM AMIN, CAMERAPIX

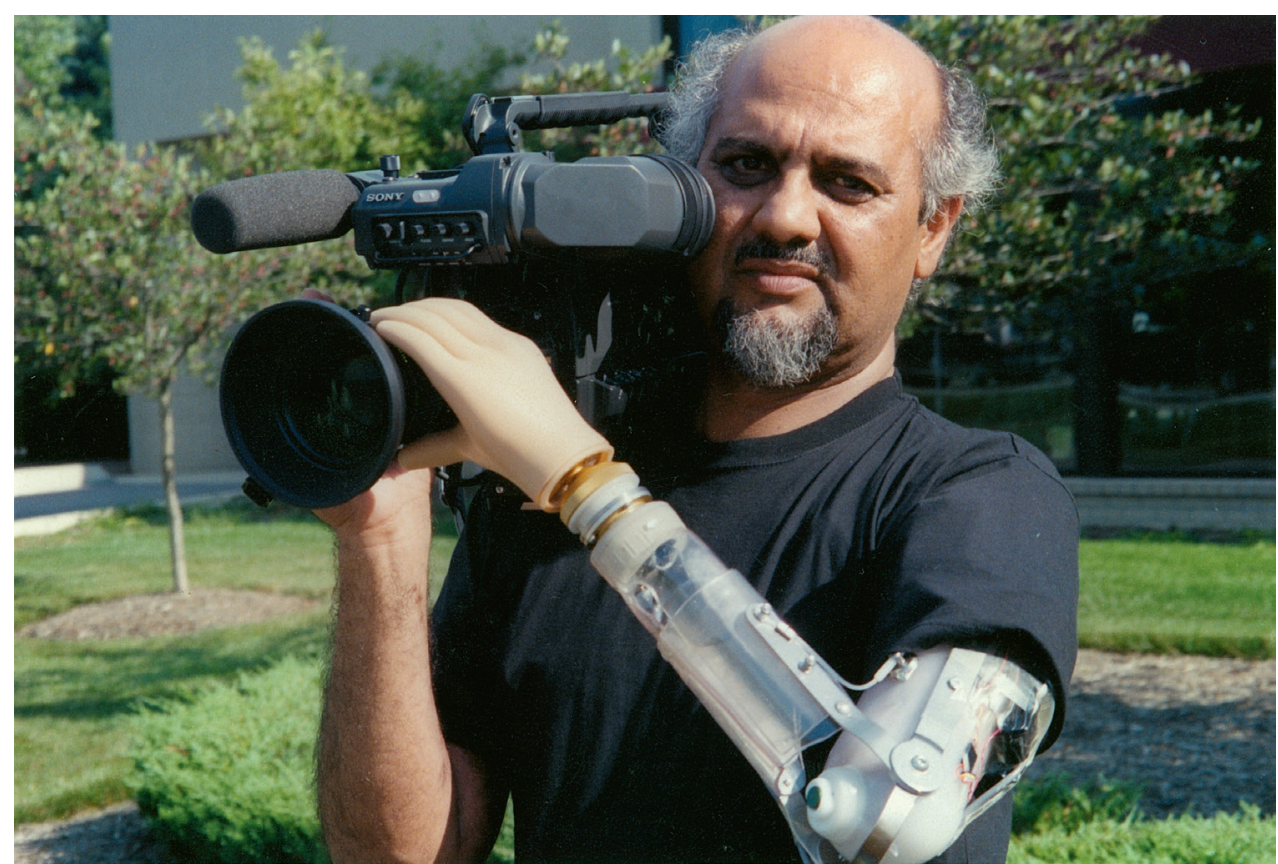

'Fareh te chareh' is a Gujarati proverb translated as 'A person who roams advances.'10

With sea-routes connecting West Africa to the Atlantic trade from the fifteenth century onward (Haney, 2010, pp. 15-55), the Indian Ocean trade-network has connected East Africa to the Arabian Peninsula and India for at least two millennia. ${ }^{11}$ The ease of maritime navigation and the seasonal winds and currents, reversing their direction every six months, enabled voyages since at least the first century, and were documented in the Greek work of Periplus of the Erythracan Sea. ${ }^{12}$

Gregory (1993, pp. 9-40) has referred to the first period of Asian migration to the earliest few centuries BCE, in small shipping vessels (Hourani and Carswell, 1995, pp. 4-5, 18-36 and 9-40) right up to the latter part of the nineteenth century. Works of early Asian studio photographers from Goa has been discussed and analysed to a small extent by Haney (2010, pp. 49-51 and 68-9) and were part of an earlier migration to East Africa from South India, as were Gujarati traders from North West India.

These small shipping vessels or dhows in the common vernacular were part of a fashionable recognized iconography depicted on postcards (fig. 4), an undeviating imagery right through to contemporary tourist literature. The particular image in fig. 4, was originally printed in a 1994 tourism guide book sponsored by the Department of Tourism in Zanzibar. The image appears on other tourist literature including postcards, as well as to illustrate an online article about the role of photography and tourism to Zanzibar. ${ }^{13}$

It has been taken by contemporary Muslim photographer Javed Jafferji (b. 1969) of East African Asian descent who is part of a family network of photographers, which is a topic of further discussion within this paper. The fishing vessel in fig. 4 is equipped with a small motor reflecting twentieth century changes in technology. The large sails and the general design of the dhow in its various forms, such as the smaller fishing abra or larger jahazi seafaring craft, has been part of the visual lexicon, in paintings, sketches and lithographs around the Indian Ocean coast (Evans, 2005). ${ }^{14}$ Oral histories in We Came in Dhows and Through Open Doors (Salvadori, 1996) mentioned arriving to the coast in stitched boats as well as boats constructed with hammered nails. 

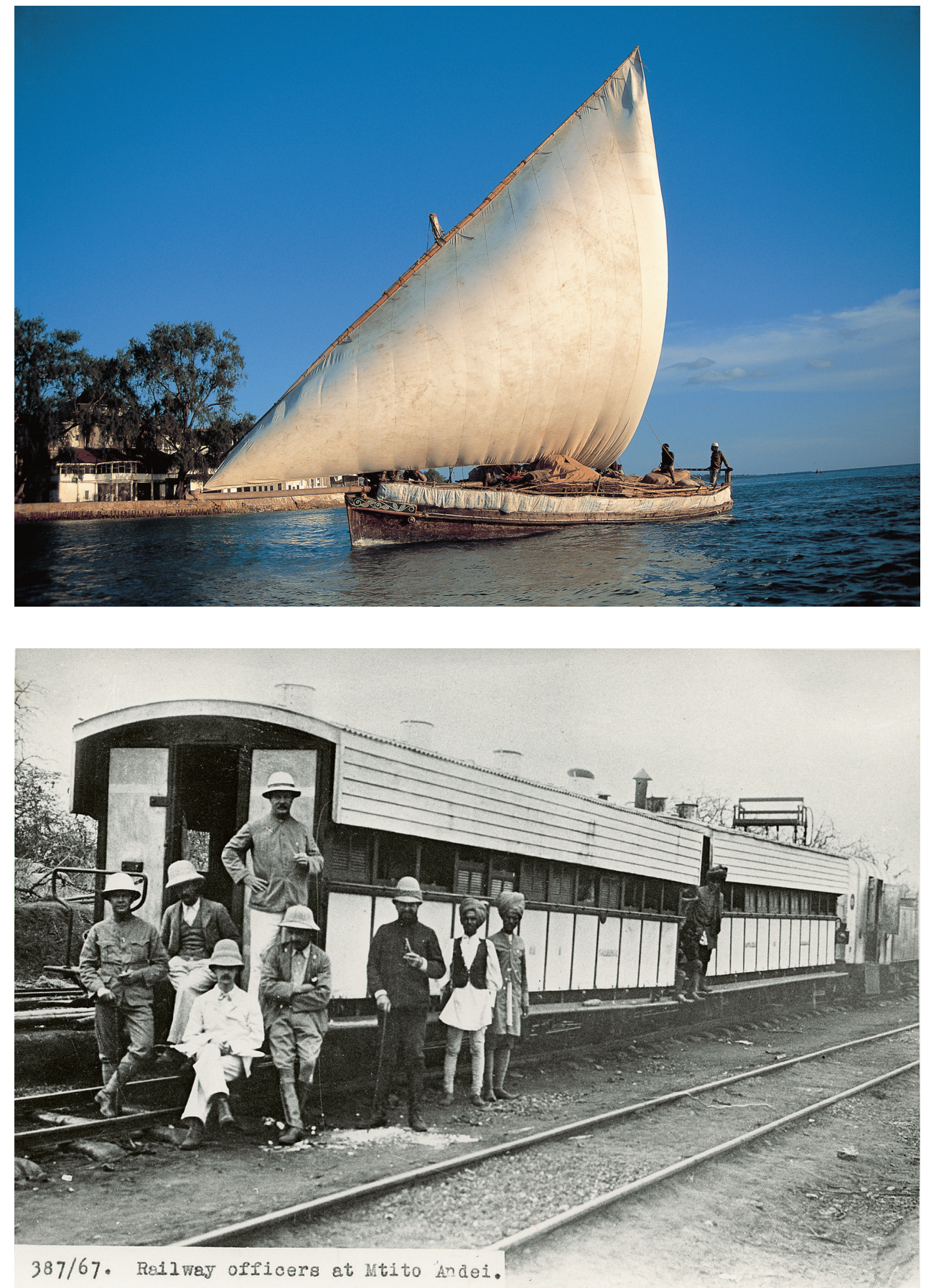

The second migratory phase has been attributed to the railway construction of the 189 os (Gregory, 1993, pp. 9-40). Fig. 5 is a regular example of a colonial era photograph documenting the Kenya-Uganda Railway construction, also dubbed the Lunatic Express $^{15}$ and depicts British army officers next to Indian members of the workforce. The photograph is organized with most of the British officers at the front of what appears to be a completed carriage. The individuals within the photograph look smartly dressed for the occasion. The few Indian staff members depicted are in the rear ground behind the British army officers. Another photograph, dated 1899 and taken by the British settler, William Young, shows hundreds of Indian indentured workers, packed together and hanging off the railway carriage (Haney, 2010, p. 52). The family history of
FIGURE 4

Dhows formed part of a recognized fashionable iconography depicted on early nineteenth century postcards right through to contemporary tourist literature.

1994 PHOTOGRAPH, COURTESY OF ZANZIBARI PHOTOGRAPHER, JAVED JAFFERJI (B. 1969)

FIGURE 5

Colonial era photograph documenting Kenya-Uganda Railway construction also dubbed the Lunatic Express and depicts British army officers next to Indian members of the work force, from 1890 s PHOTOGRAPHER UNKNOWN, COURTESY OF SALIM AMIN, CAMERAPIX 
photojournalist Mo Amin stems from this second wave of migration from India. Fig. 5 is now part of the late Mo Amin's Camerapix company's photographic archive.

\section{$4 \quad$ Early Photography in the Region}

Works of early Asian studio photographers from Goa has been discussed and analysed to a small extent (Haney, 2010, pp. 33, 49-51, and 68) plus a selection of postcards intended for European visitors and audiences (Evans, 2005) ${ }^{16}$ Of the early history of photography, Haney (2010, pp. 43-55) includes the East African mainland, Horn of Africa, and the Indian Ocean Islands, which records the arrival of European photographic practice from 1840 in the Mauritius capital of Port Louis, to a place with an established network of artists and engravers. Mauritius, Madagascar and the Seychelles acted as strategic points for eighteenth century France's colonial ambitions.

From 1840, just about a similar time photography was in use in India, (Pinney, 1997, pp. 17-71) daguerreotype and calotype photographic processes were widely in use in Mauritius. During this period a number of studios provided affordable photographic services to local patrons, while the elite opted for more painted portraiture. Emy and Tardieu, Evariste Letourneur, Lemaire, Trood brothers and others opened within a few years of photography's arrival (Haney, 2010 pp. 44-49).

The ruling elite patronized a long tradition of locally painted portraiture. Haney (2010, pp. 44-9) has suggested that a black and white photograph when compared to a vibrant nineteenth century portrait, may have been less appealing at the time. Benjamin writing in Illuminations has referred to a loss of 'aura', which is intact in an original piece of art, but diminishes in a photograph, which has the capability of reproducibility, a conception often cited by scholars. ${ }^{17}$ Early photographic portraits adopted the characteristic of the 'swagger' sort described by Pinney (1997, pp. 72-107) where the subject adopts a pose with lavish accessories, acting for symbols of wealth, power and status, often a familiar sight in painted royal and other portraiture. ${ }^{18}$

In 1868, A.C. Gomes from Goa opened a studio in Zanzibar and was part of the earlier migration to East Africa from South India. Postcards by A.C. Gomes and Son, de Lord, Continho Bros, Ali Pira Harji, Karim Essa Allibhai, and others are catalogued in Early Postcards of Zanzibar (Evans, 2005). It is a rich directory of postcards, and although some factual material is provided, it is not designed as a work of argument. The visual topography within this collection is reminiscent of 'human type'/'occupation' photography, festival depiction, colonial trade, local elites including the Indian merchant class, staged tableaux and possibly photographs that were commissioned privately, but were printed for wider circulation. Haney (2010 pp. 51) has posed the question of whether permission for the latter was sought or not.

The scholar Gisbert Oonk (2004 and 2009) has written extensively on a prominent Indian merchant family, the Karimjee Jivanjees. The works include photographs that were most likely commissioned from Zanzibar's early studios.

Anisah Ebrahimjee (Table 1) is the great-granddaughter of Mohamedali Karimjee from her mother's side of the family. She has shared some of the Karimjee Jivanjee's family's private collection of photographs within this paper, together with examples from her paternal great-grandfather's archive, which directly reference some of the early studios. Fig. 6 is a photograph taken at Gomes's studio. The image depicts Anisah Ebrahimjee's paternal great-grandfather, Ebrahim Sheikh Esmailjee with his children, Sukan and Fazalabbas Ebrahimjee. It is most certainly an example of a photograph taken by a Gomes photographer as identified by the sticker on the mount. The photograph is reminiscent of a Victorian parlour and patrons posing with objects of their 


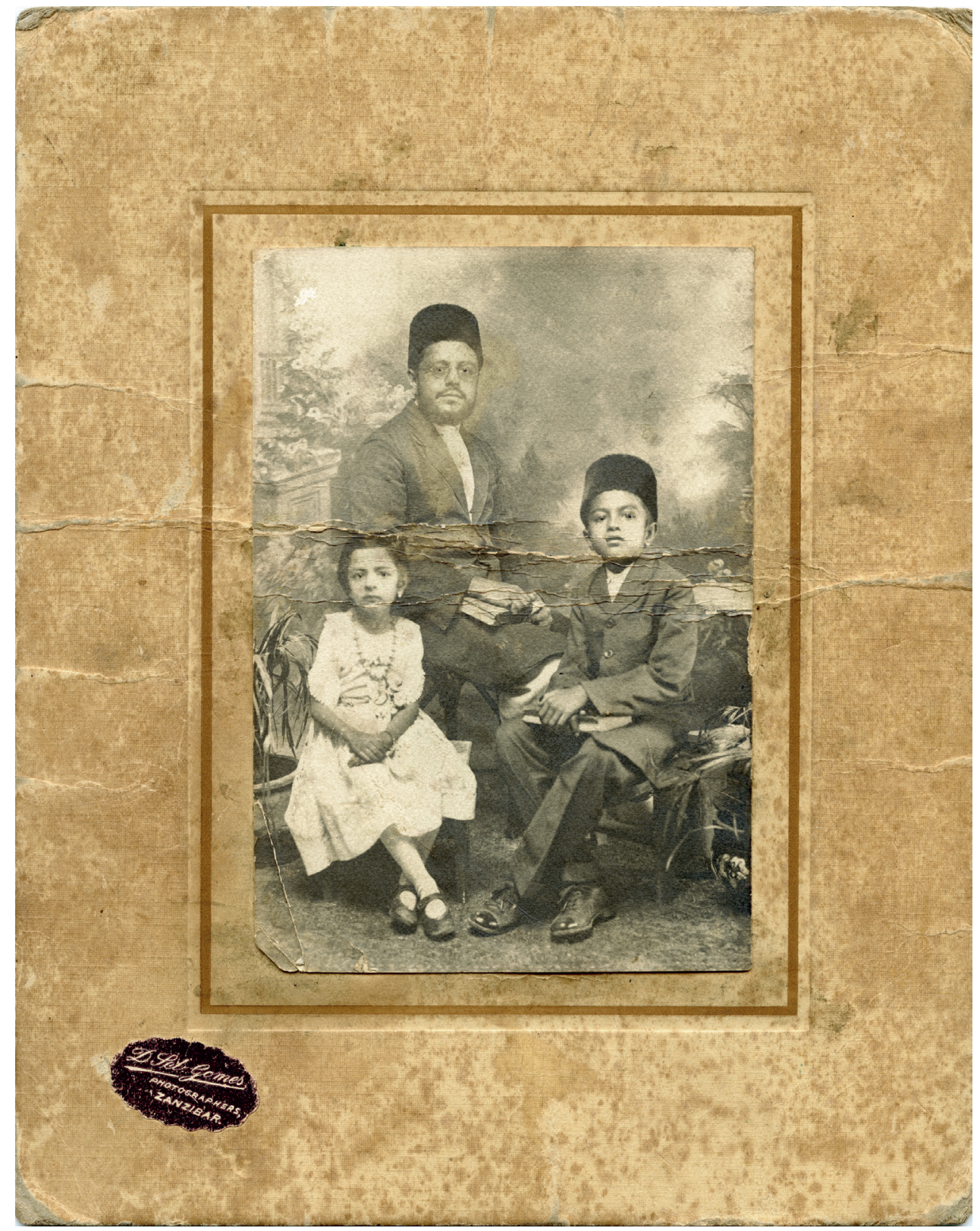

choice. Similar imagery is portrayed in Oonk's Asians in East Africa, Images: Histories, and Portraits (2004).

Ebrahim Sheikh Esmailjee was from the Shi'i Fatimi Taiyibi Isma'ili Dawah denomination of Islam, or more ordinarily known as Dawoodi Bohra or Bohra. ${ }^{19}$ His father, Sheikh Esmailjee Ebrahimjee moved from Mandvi in India, to Zanzibar in the 18oos, to lead the growing community to support its religious welfare.

Anisah Ebrahimjee considers the photograph to date back to the mid 1920s and during a period when her great-grandfather was widowed. The family is dressed in fashionable clothing of the epoch and father and son are wearing a smart generic cap or topi worn by Muslims. The books clasped by the father and son may allude to the importance of scholarship in the family. 'Sheikh Esmailjee wanted his son Ebrahim to become a religious scholar, perhaps that could be why the books are there in the photograph. However my great-grandfather chose to go into the watch merchandise business. He was passionate about watches and clocks and declined to take up the role as the head of the masjid, even though he had been trained to do so.'

\section{FIGURE 6}

Ebrahim Sheikh Esmailjee and family, from late 1920s, taken at A.C. Gomes and sons, one of Zanzibar's earliest studios, indicated by the sticker on mount. Dimensions: Photo: Length $15 \mathrm{~cm}$ $\times$ Width $10.4 \mathrm{~cm}$. With mount: Length $25.3 \mathrm{~cm} \times$ Width $20 \mathrm{~cm}$ COURTESY OF GREAT GRANDDAUGHTER, ANISAH EBRAHIMJEE'S PRIVATE FAMILY COLLECTION 
The case study of studio photographer Tayabali Hassanali Adamjee, 1901-94, offers valuable insights from the early part of twentieth century Zanzibar, into the art and craft of studio photography and the manner in which rich archives become dispersed and lost.

\subsection{Zanzibar Studio and Archive of Tayabali Hassanali Adamjee, 1901-94}

'My grandfather never believed in making a lot of profit. He always used to say, just make enough to get by.'

The above is a quote from Fatima Sadikot (Table 1), the granddaughter of Tayabali Hassanali Adamjee.

Born in Mombasa in 1901, Tayabali Hassanali Adamjee in common with Ebrahim Sheikh Esmailjee, was of Dawoodi Bohra heritage. Tayabali Hassanali Adamjee (fig. 3) descended from a family principally involved in trading textiles.

Fig. 3 shows a passport photograph, which was most likely taken in his studio by an assistant. The studio was frequented by patrons for various purposes, and to make passport sized photographs for identification documents. In this photograph of the photographer, Tayabali is wearing a similar generic Muslim topi that Ebrahim Sheikh Esmailjee is wearing in fig. 6 .

Tayabali's granddaughter, Fatima Sadikot believes he started his self-taught photographic career in his twenties, at the Kiponde St studio in Zanzibar. By 1971, the studio was run principally by his photographer son, Abid Tayabali Hassanali who died in 1998 (fig. 7).

Fig. 7 is taken at the Kiponde St studio and shows Tayabali's son Abid on the right and Tayabali's nephew on the left of Abid (Sheikh-Miller, 2015, p. 39). This photograph exhibits one, of a number of backdrops, lighting equipment and stools.

Despite the fact Tayabali chose to become a photographer rather than stay within the family's textile business, the photography business was passed on, as a family concern to Tayabali's son Abid. Similarly Ebrahim Sheikh Esmailjee's descendants became watch merchants and are now known by the nickname Garialis (an association with watches in the Gujarati language).

The Kiponde St studio was configured to a familiar spatial idiom (Pinney, 1997, p. 96) of elegant salon with furniture; props and backdrop, assisting collaborative creative engagement, between photographer and patron (figs. 8-9).

FIGURE 7

Abid Tayabali Hassanali (right) at the Kiponde St Studio in Zanzibar. By 1971, the studio was principally run by Tayabali's son Abid. The studio was configured to a familiar spatial idiom of an elegant Victorian salon with furniture. PHOTOGRAPH BY AN UNKNOWN PHOTOGRAPHER, COURTESY OF FATIMA SADIKOT'S PRIVATE COLLECTION

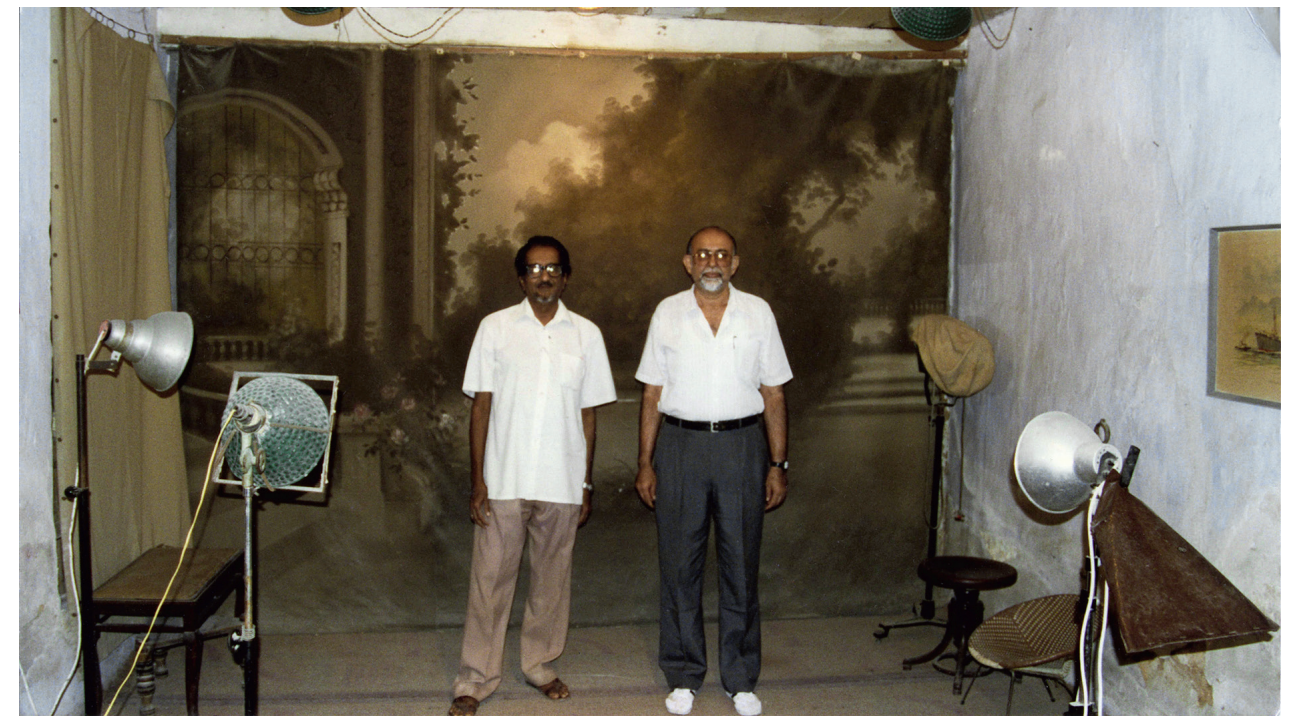



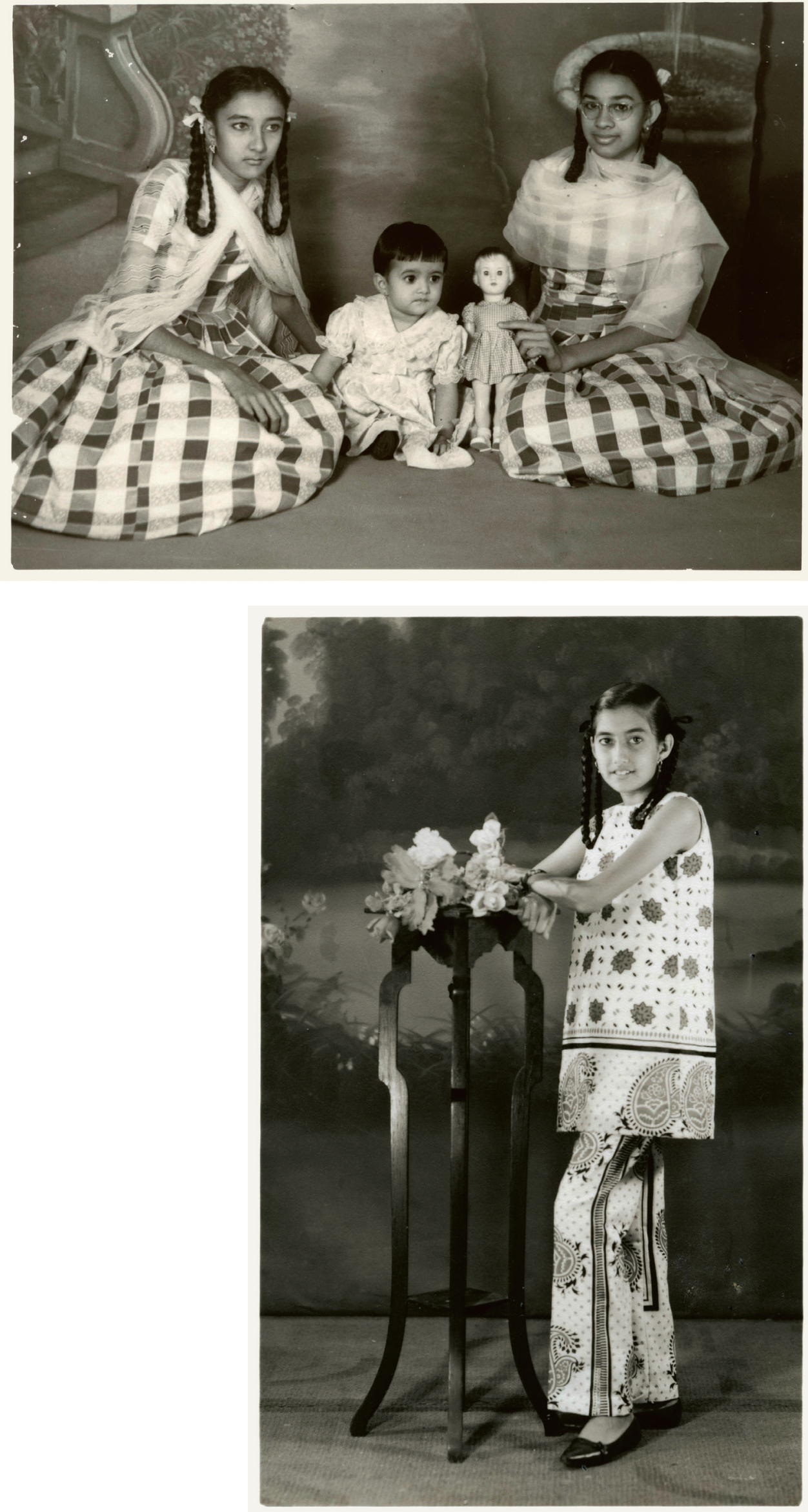

FIGURE 8

Photograph from 1950s by Tayabali Hassanali Adamjee, from left, photographer's daughter, Rashida, granddaughter Fatima and Rashida's friend, Bushra, Zanzibar, Tanzania

PHOTOGRAPH, COURTESY OF FATIMA SADIKOT'S PRIVATE COLLECTION
FIGURE 9

Fatima Sadikot's childhood photograph from the 196os, in the first outfit she stitched

PHOTOGRAPH BY TAYABALI HASSANALI ADAMJEE, COURTESY OF FATIMA SADIKOT'S PRIVATE COLLECTION 
Agfa Gevaert supplied equipment, chemicals, colour tints etc. however props such as a parasol and silk flowers were purchased from Japan. Tayabali was keen to learn from photographic text books and almanacs. He also imported cameras and equipment to sell.

Figs. 8 and 9 are photographs taken by Tayabali. Fatima Sadikot is present in both. She was the most photographed of all the family members. Fig. 8 marked the occasion of Fatima's first birthday (Sheikh-Miller, 2015, p. 45). The two girls are Fatima's aunt, Rashida (daughter of Tayabali), and her best friend Bushra. The identical checked design cotton dresses were stitched for the celebration and the fabric was from Bushra's maternal uncle's fabric shop, which sold textiles. Fatima's first doll, a present she received for her birthday is in the photograph and her only doll for several years, 'I was one of those that treasured things.'

In fig. 9, Fatima is now an older child and she recollects that the occasion was Eid. The outfit she is wearing was also stitched by her, having had help from her aunt, to cut the fabric according to the pattern. The textile is the brightly printed local kanga material often with a Swahili proverb along the border. 'It is pure cotton and versatile and at that time we would use locally available fabrics. After the revolution and particularly between 1965 and 1968, most imports had stopped.'

As above, photographs would be commissioned to mark special occasions, rites of passage, such as before or after Hajj pilgrimage, male circumcision, family photographs and reunions, weddings (fig. 10) and festivals such as Eid, Diwali and Christmas.

FIGURE 10

Couple, Turab and Khatun Chakera, marking their special occasion, from 193 os by Tayabali Hassanali Adamjee, Zanzibar,

\section{Tanzania}

PHOTOGRAPH, COURTESY OF FATIMA SADIKOT'S PRIVATE COLLECTION

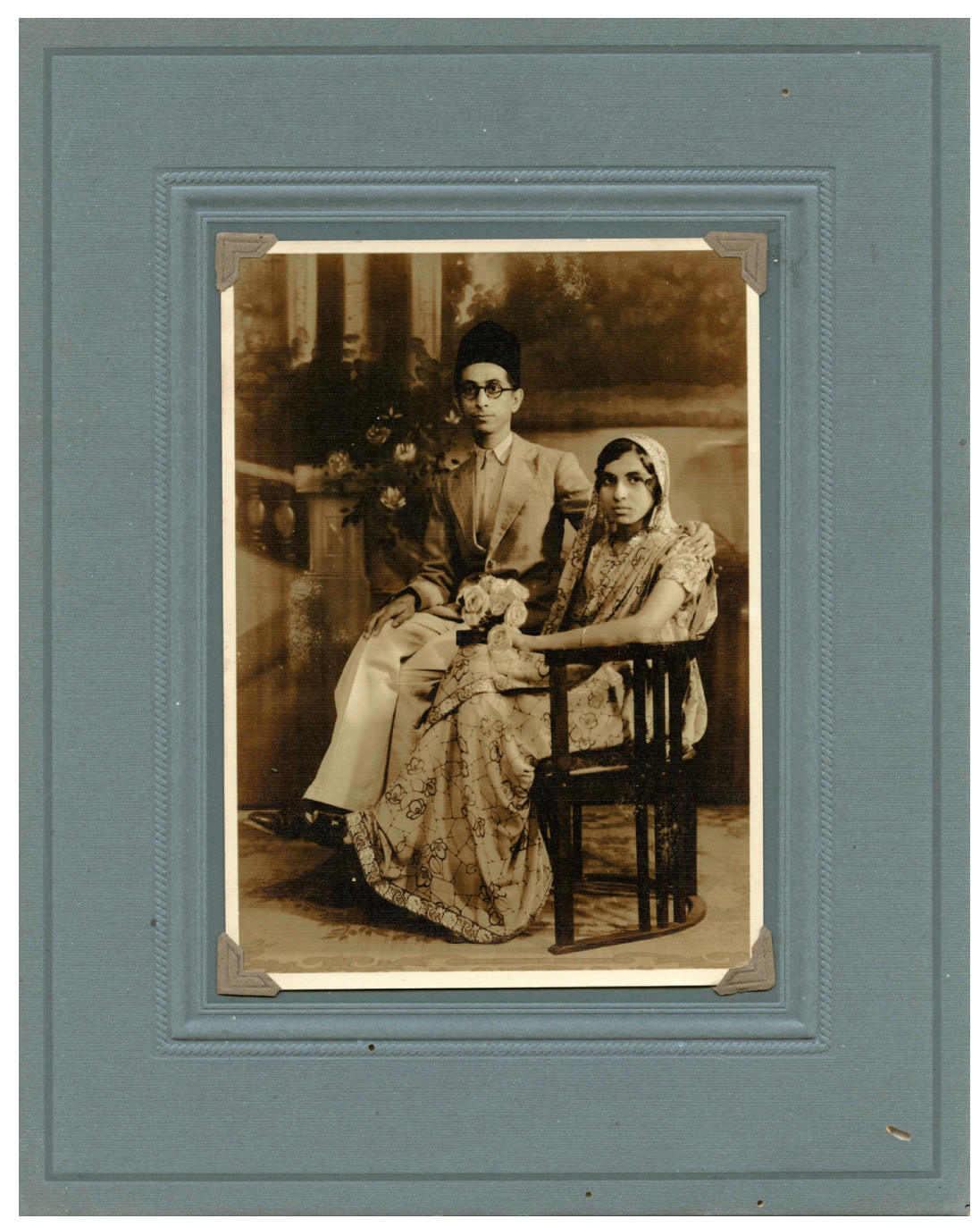


Within the family collection and published in Sheikh-Miller (2015 p. 45), there's a photograph from the 1960s of Fatima's older brother Moiz, wearing a silk kurta outfit and a garland of flowers. This photograph was taken after circumcision. Fig. 10 is a much earlier calotype photograph of a young couple, Yusuf and Khatun Chakera marking their engagement or marriage, who were from a Dawoodi Bohra merchant trader family. The silk flowers are most probably from the studio and the topi the groom is wearing, is similar to those in fig. 1 and fig. 6 . According to Fatima, most head attire was bought from the Topiwala shop in Zanzibar.

Fig. 11 is an earlier family portrait of Ebrahim Sheikh Esmailjee than the one in fig. 6. Fig. 11 is not identifiable to an individual studio as the stickered one from the Gomes studio. The spatial architecture in fig. 11 is more luxurious, comprises a rug, pot plants and a dramatic backdrop. Ebrahim Sheikh Esmailjee is wearing a pocket watch, pinned to his lapel, perhaps reflecting his chosen profession; trading in watches and clocks. There is also an aesthetic element to the spatial geography of the family portrait. It is reasonable to hypothesize that this could be one of Tayabali Hassanali Adamjee's earlier photographs. Fatima Sadikot mentioned that it was not until much later when her grandfather's studio started to identify its photographs.

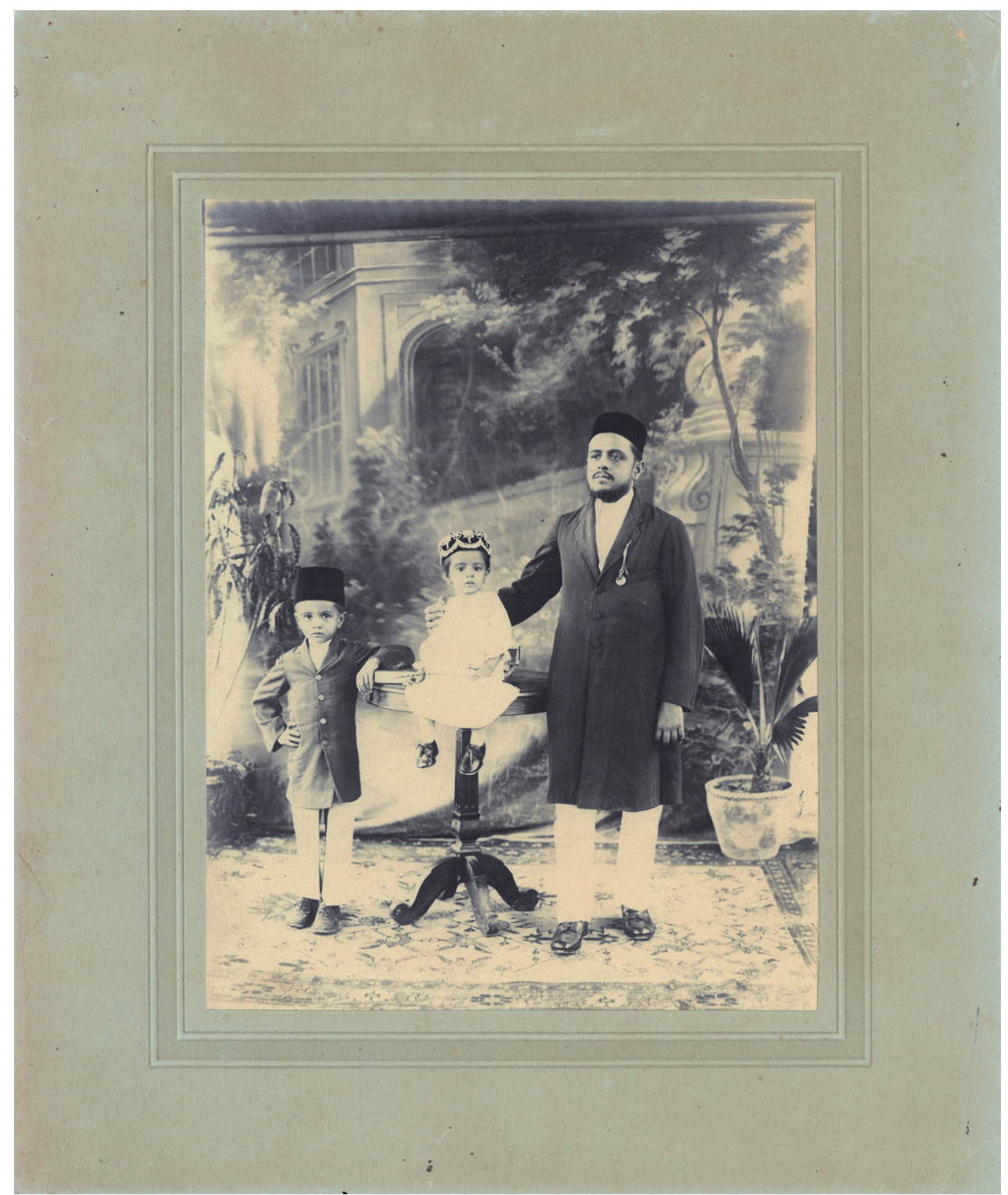

FIGURE 11

Ebrahim Sheikh Esmailjee and family from mid 1920s, Zanzibar, and unknown photographer. Ebrahim is wearing a pocket watch and may allude to his chosen profession of watch merchant. Spatial geometry may indicate an early photograph by Tayabali Hassanali, Adamjee. Dimensions: Photo: Length $25 \mathrm{~cm}$ $\times$ Width $15.5 \mathrm{~cm}$. With mount: Length $30.5 \mathrm{~cm} \times$ Width $23 \mathrm{~cm}$ COURTESY OF GREAT GRANDDAUGHTER, ANISAH EBRAHIMJEE'S PRIVATE FAMILY COLLECTION 
FIGURE 12

Snapshot, of Sultan Said Sir Khalifa II bin Harub Al Said on an informal visit to Sir Tayabali Karimjee's family home in Zanzibar, from 1950s. Dimensions: Length $8.5 \mathrm{~cm} \times$ Width $6.1 \mathrm{~cm}$. Photographer unknown COURTESY OF MATERNAL GREAT GRANDDAUGHTER, ANISAH EBRAHIMJEE'S PRIVATE FAMILY COLLECTION

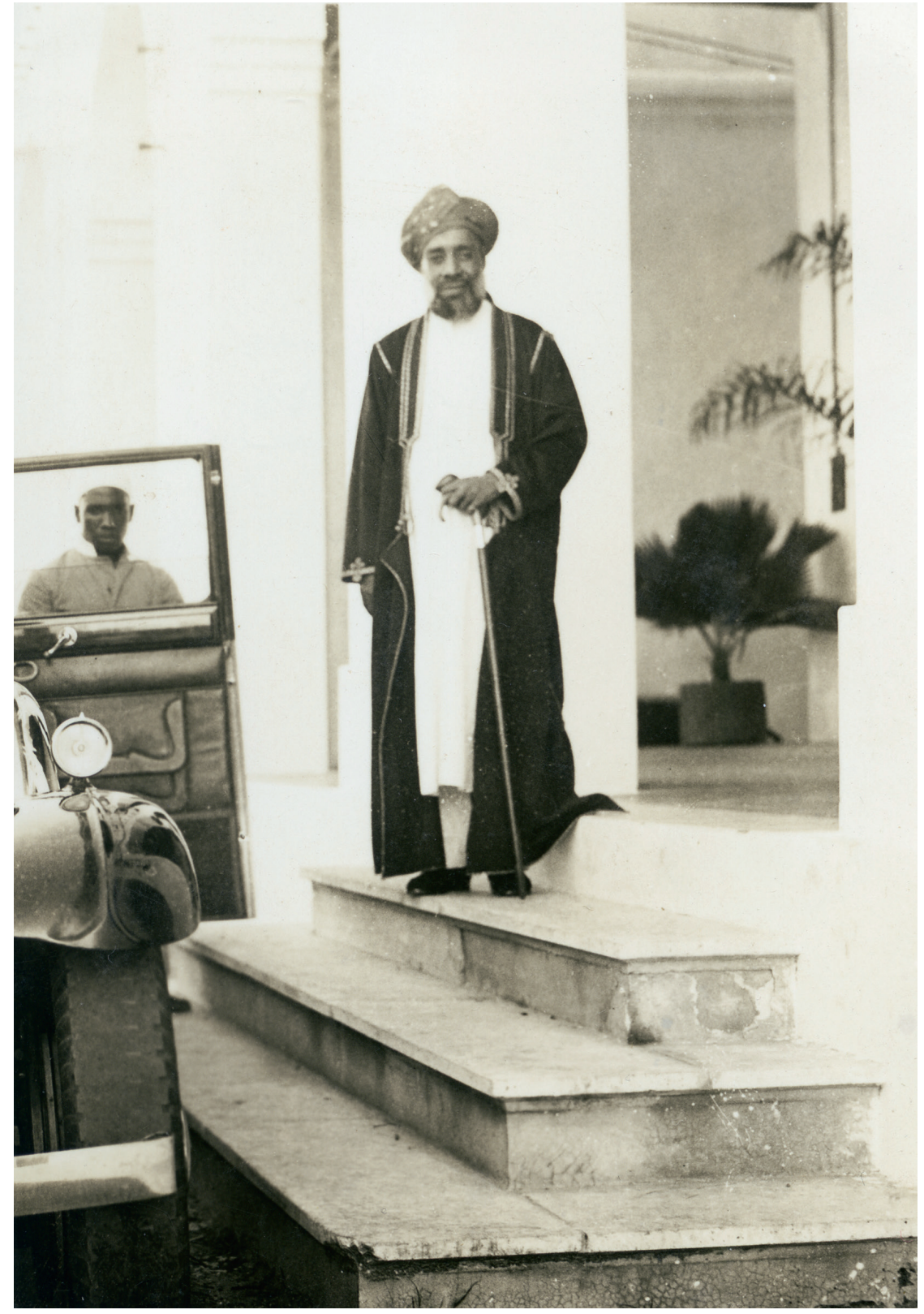

'African families, Indians, Parsis, Persians, Arabs, everyone came, I remember the Persian ladies would really dress up. All negatives would be returned to them, they arrived in full purdah. They trusted him. There were stylish clothes for people to wear if they wanted.

Patrons included influential clients, the Sultan and his family, Ruwehy family (members of the local elite), Dawoodi Bohra heritage Karimjee Jivanjees, the Aga Khan's family, British royal visitors as well as patrons from Zanzibar's diverse communities.

There are two photographs of interest figs. 12 and 13 within the private collection of the Karimjee Jivanjee family. These have been taken with a personal camera dating back to the 195os. Tayabali Hassanali Adamjee sold cameras for those in the photographic trade, for hobbyists or for personal use. These were expensive imported items at the time and would require a degree of wealth to own one. The Karimjee Jivanjee family had most probably bought theirs on a trip to Europe.

Fig. 12 is part of Anisah Ebrahimjee's personal collection whose maternal heritage stems from the Karimjee Jivanjee family. It might have been taken at the family home of her maternal great uncle's in Zanzibar, Sir Tayabali Karimjee who was on friendly terms 


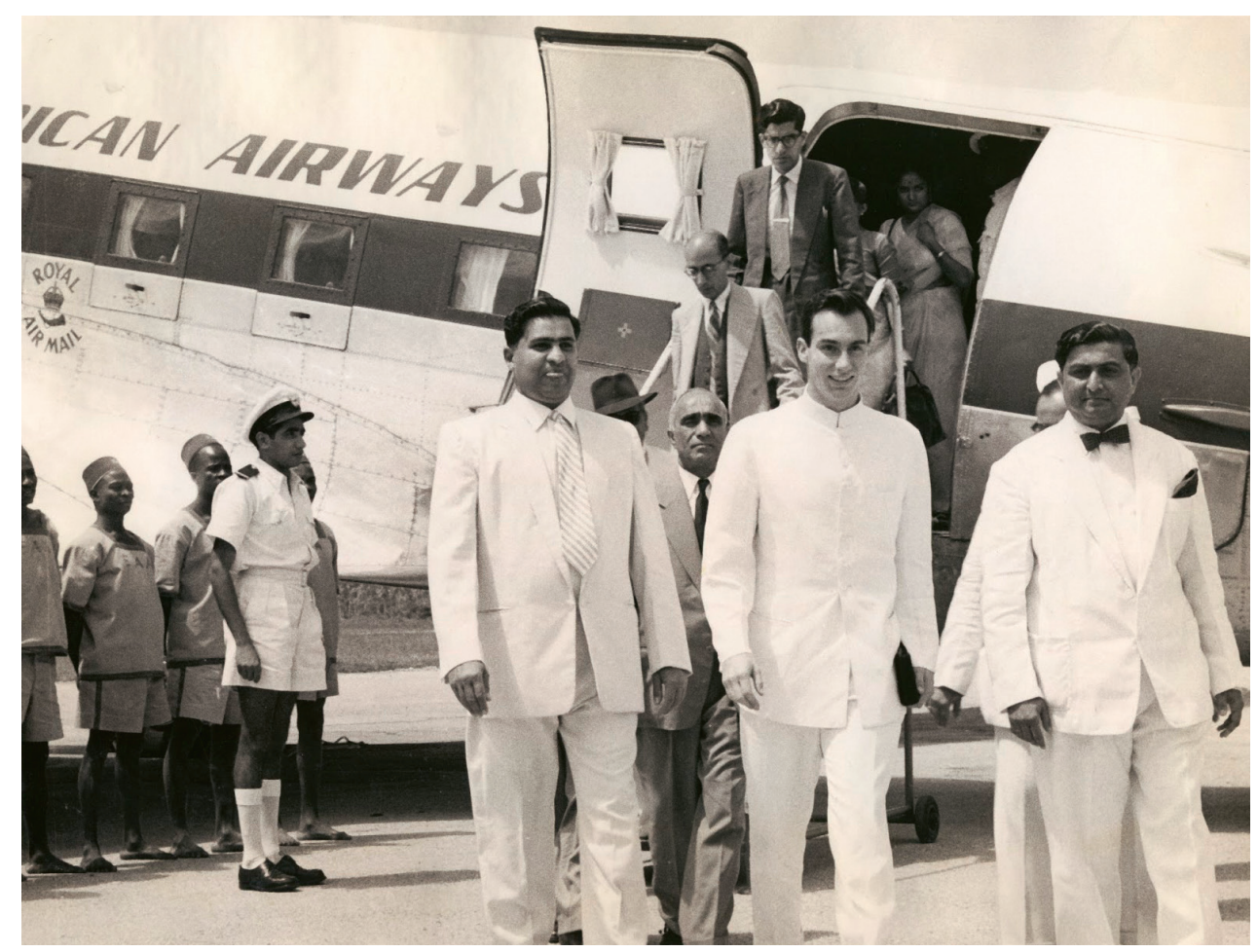

with the Sultan (Oonk, 2009, pp. 138-48). Sir Tayabali Karimjee received a knighthood from the British government for his major contributions to the welfare of local communities in 1948. Fig. 12 is a small 195os snapshot photograph of Zanzibar's Sultan from the period, Said Sir Khalifa II bin Harub al Said making an informal visit. There's a recognisable sense of familiarity and warmth expressed within the photograph.

Fig. 13 is a photograph of Prince Shah Karim al Husseini on a 1957 visit to Tanga, Tanzania, and in the year he became Aga Khan Iv. Prince Shah Karim al Husseini has just arrived at Tanga airport flanked by two Isma'ili personages. He was hosted at the Karimjee home.

In Fatima Sadikot's private collection (fig. 14) is a photograph taken by Tayabali Hassanali Adamjee documenting a visit to Zanzibar by Prince Aly Salman Aga Khan, the current Aga Khan's father, hosted by the Isma'ili community. Hanging on the walls are photographs of the Sultan, Sayyid Sir Khalifa II bin Harub al Said (Lyne and Wilson 2006, p.180) and the British King, George VI, the father of the current Queen Elizabeth II.

In 1964, during the revolution in Zanzibar, the photographer's family was forced to destroy images taken of the Sultans in case it put their lives in danger. 'Confiscating the photographs broke my grandfather's heart.' With the exception of returned photographs or those lost in the revolution, every copy in the seventy-five years or so of operation, was at the premises.

After Abid's death in 1998, copies were returned to known patrons with remaining photographs and cameras dispersed among family members and some equipment given away to local photographers. Haney (2010, p. 55) has discussed the scattering of archives, in this instance, political and social factors and the studio's closure led to the dispersal of the collection.

Tayabali Hassanali Adamjee was also the personal photographer of the Karimjee Jivanjee family (fig. 15) and as mentioned earlier, the family was part of the business elite of East Africa. Gijsbert Oonk's (2004) work, Asians in East Africa: Images, Histories
FIGURE 13

Prince Shah Karim Al Husseini, 1957, arriving at Tanga airport, with two Isma'ili personages. Prince Shah Karim was hosted at the Karimjee home in Tanga. Photographer unknown. Possibly taken with a personal camera COURTESY OF KARIMJEE JIVANJEE PRIVATE FAMILY COLLECTION 
FIGURE 14

Photograph of Prince Aly Salman Aga Khan, the son of Sir Sultan Muhammad Shah Aga Khan III, by Tayabali Hassanali Adamjee, visiting the Isma'ili community in Zanzibar, Tanzania

PHOTOGRAPH, FROM 1930S OR 1940S, COURTESY OF FATIMA SADIKOT'S PRIVATE COLLECTION

FIGURE 15

Family photograph from the 193os of Sir Yusafali Karimjee (centre) and a possible visitor. Sir Yusafali was also responsible for the Karimjee Jivanjee education foundations. Photograph was published by Oonk, in 2004, studying the histories of Asian families in East Africa. The book did not identify photographers. Tayabali Hassanali Adamjee was an official photographer of the Karimjee Jivanjee family. The locale, setting and the nature of the image have qualities in common with photographs taken at his Kiponde studio in Zanzibar. COURTESY OF KARIMJEE JIVANJEE PRIVATE FAMILY COLLECTION
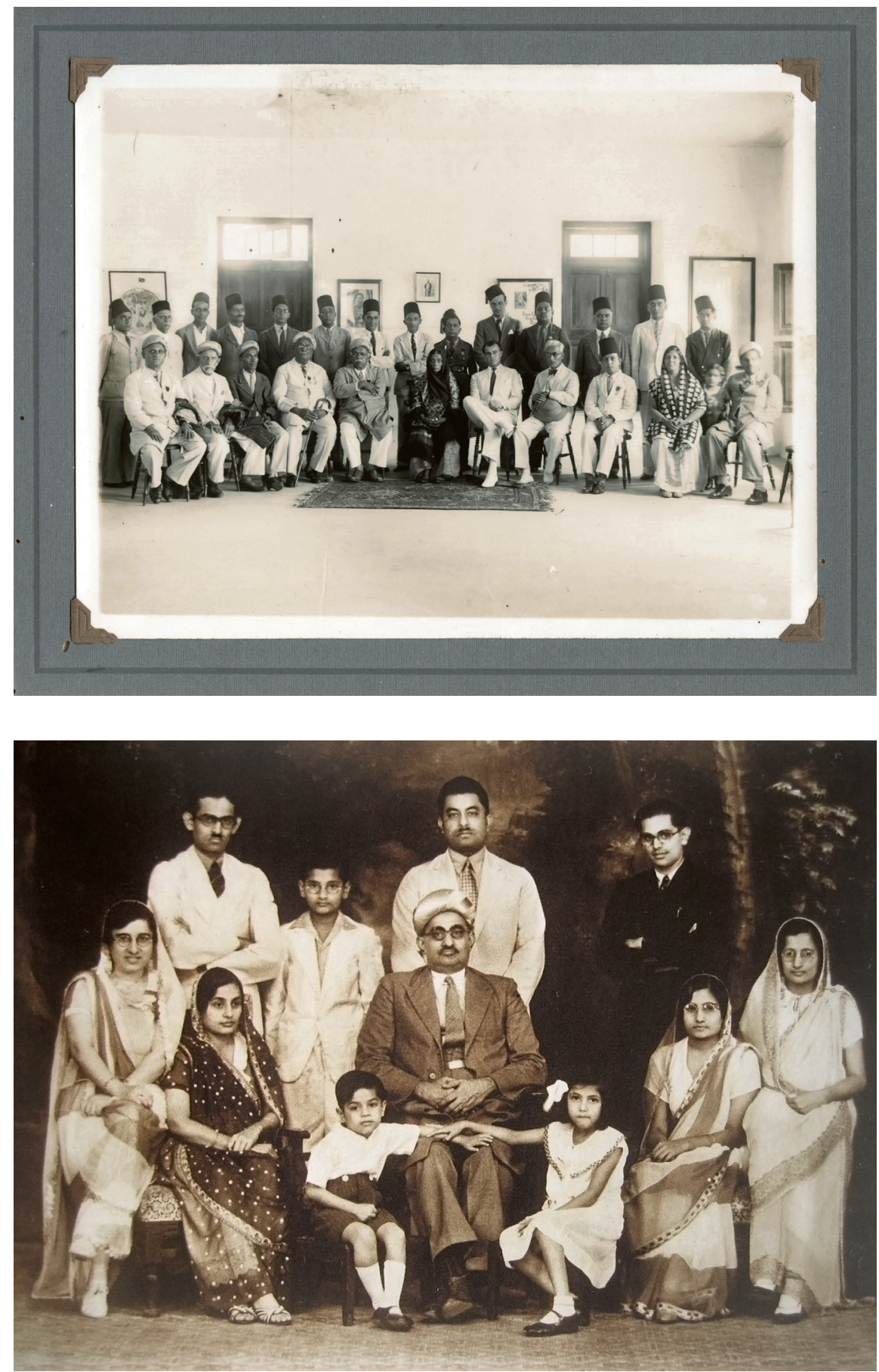

and Portraits is the first academic piece that places emphasis on the scrutiny of photographs of Asians in East Africa. Recently he was asked to write a second book (Oonk, 2009) by a Karimjee family member, the late Hatim Karimjee whose merchant family's extensive history was one of the main case studies in Oonk's previous publication (Karimjee's forebear, Jiwanjee Budhabhoy, arrived in Zanzibar in 1818).

Oonk has maintained that he has gone further than others by reconstructing the context concerning the photograph. He deems that questioning the reasons why, and how an image has been taken, is just as worthy as the representation of that image.

Although Oonk (2004, pp. 20-1, 40-1 and p. 47) included many photographs of the Karimjee Jivanjees in his book, he did not identify the photographers. It is plausible once 
again to assume that some photographs were by Tayabali Hassanali Adamjee. Fig. 15 is a particular photograph of interest, possibly dating to the 193os, of Sir Yusufali Karimjee (1882-1966) and family. The locale, setting and nature of the image have qualities in common with photographs taken at the Kiponde St studio. Fatima Sadikot is certain that this particular photograph was taken at her grandfather's studio, through recognizing the style of backdrop and the stylized positioning of the subjects in the photograph.

Anisah Ebrahimjee, the maternal great-grandniece of Sir Yusufali Karimjee, researched the photograph with her other family members. They were able to name everyone except for the gentleman in the middle back row. Though regular family photographs were professionally taken at various intervals, it is possible that this photograph may have been organized to mark a visit by a guest of the family.

Sir Yusufali Karimjee was a noteworthy advocate for education and received a knighthood from the British government for his dedication to the philanthropic role of the Karimjee Jivanjee trusts, which also granted scholarships for Bohra students to study abroad (Oonk, 2009 pp. 127-37).

In Oonk's (2009) publication, The Karimjee Jivanjee Family, Merchant Princes of East Africa, 1800-2000, a number of the photographs could have been attributed to the work of Tayabali Hassanali Adamjee, including what Anisah Ebrahimjee has described as an 'iconic' photograph (fig. 16) on the front cover of the publication. It is possible that this may have been one of his first assignments. The 1924 photograph was taken outside

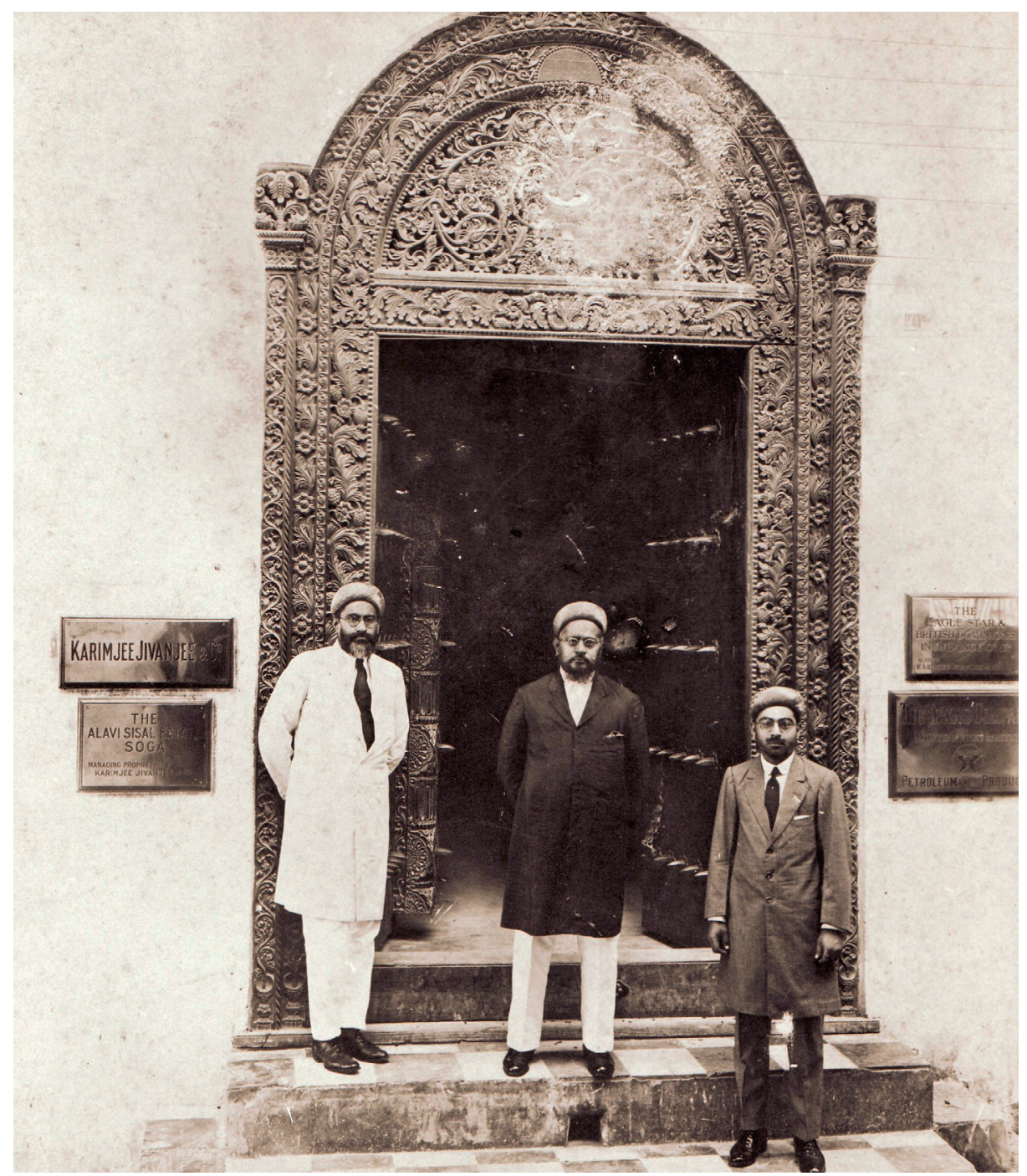

FIGURE 16

'Iconic' photograph of Karimjee Jivanjee family on the front cover of Oonk's (2009) publication, of Sir Yusafali Karimjee, Mohamedali Karimjee and nephew Sir Tayabali Karimjee, outside Karimjee Jivanjee and Co. Offices, 1924, Zanzibar. This may have been one of photographer Tayabali Hassanali Adamjee's first assignments.

COURTESY OF KARIMJEE JIVANJEE PERSONAL FAMILY COLLECTION 
FIGURE 17

Memorial photograph of Ebrahim Sheikh Esmailjee made by his son Fazalabbas after his father's death in 1948. The formal photograph, displays the detail of the embroidery pattern of the feto topi. Photographer unknown, but it is conceivable that it was taken by Tayabali Hassanali Adamjee. COURTESY OF ANISAH EBRAHIMJEE'S PERSONAL FAMILY COLLECTION

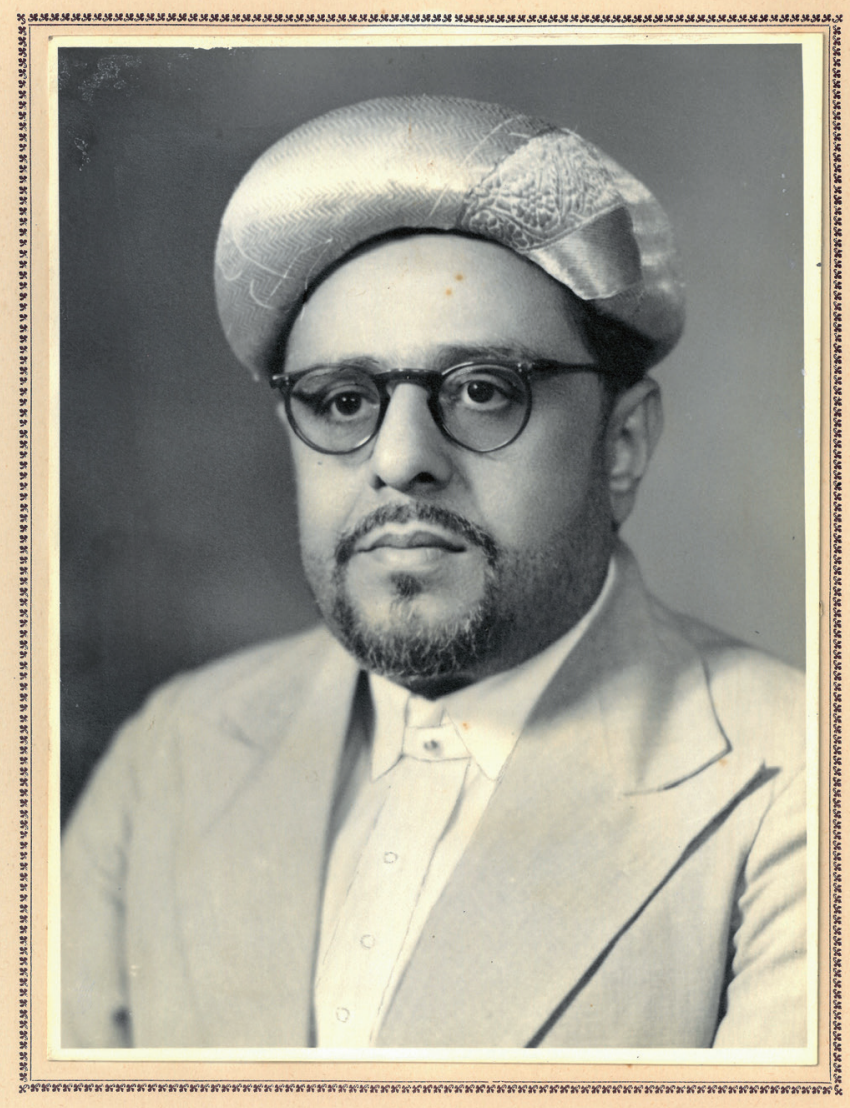

THE LATE EBRAHIM SHEIKM ESMAIL J

EXPIRED AT ZANZIBAR ON 13 th MAY 1948, 5 th RAJAB 1367.

the Karimjee Jivanjee and Co. offices in Zanzibar. Sir Yusafali Karimjee, Mohamedali Karimjee and their nephew Sir Tayabali Karimjee the son of the elder brother, Hassanali Karimjee. They are all wearing the golden feto topi, which is commonly worn by Dawoodi Bohras on formal occasions. Sir Yusufali Karimjee is also wearing a feto topi in fig. 15 .

The photograph in fig. 17 was adopted as a tribute by Fazalabbas, the son of Ebrahim Sheikh Esmailjee. It was taken not long before his father's death in 1948. The photographer is not named however this too could be a portrait by Tayabali Hassanali Adamjee. The photograph furthermore displays the detail of the embroidery pattern on the feto topi. Pinney (1997) writes extensively about the importance of commemorative photographs to the patrons of the Nagda Studio in India (Pinney, 1997, pp. 175-86).

The daguerreotype photograph (fig. 16) of the three key family members in the foreground of the Karimjee Jivanjee headquarters, is spatially choreographed in front of the distinctive carved wooden portal and studded doors. According to Anisah Ebrahimjee, the two brass plaques displaying the company name and other details were specially commissioned. The family lived in apartments above the building before moving to more spacious villas at a later time. Anisah Ebrahimjee has spoken of this photograph 'as one which everyone in the family recognizes, and it is often used on invitations 


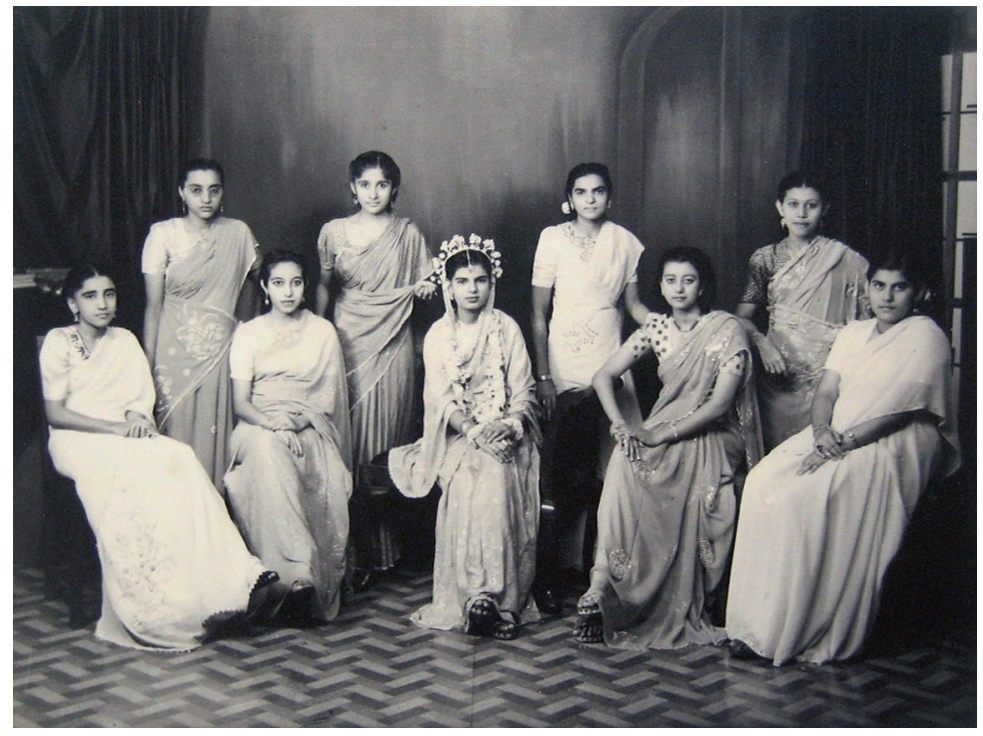

for our annual business dinners and other literature. The building was bought by the Karimjee Jivanjee family from the influential business trader, Tharia Thopan who was Sultan Baragash's chief of customs (Salvadori, 1996), in the last quarter of the nineteenth century. It is now the National Bank of Zanzibar (Oonk, 2009, pp. 104-37 and 161-7).

A photograph taken by Tayabali Hassanali Adamjee, which is held in Fatima Sadikot's collection, and described as the Karimjee family hosting European visitors at their home (Sheikh-Miller, 2015, p. 40), might be a group photograph of colleagues working in the Karimjee Jivanjee head offices (fig. 16) in Zanzibar and possibly taken in the courtyard (according to Anisah Ebrahimjee).

Private Worlds of Patronage and Kenya's Modernist Studios

Photographs depicting non-newsworthy events in private worlds of patronage offer multi-faceted narratives and microcosms of everyday life. They can also offer added dimensions on the art and craft of photographic practises in play, among the modernist studios of Mombasa and Nairobi.

\subsection{Social Lives and Changeable Dispositions of Photographs}

Hamida Essajee (Table 1 and fig. 18-19) has kept intact her personal set of studio photographs from visits to Mombasa studios in the 1940s. Hamida's heritage is Dawoodi Bohra in common with a number of the individuals who have shared their private collections of photographs.

Fig. 18 is a studio photograph by modernist photographer of Gujarati Hindu heritage, Narayandas V. Parekh (1923-2007). In 1942, Parekh opened Victory Studio in Mombasa. Fig. 18 is a photograph of a bride and bridesmaids sitting beside her. Hamida is sitting on the far left of the frame. In this example, the bridesmaids are not covering their heads. According to Hamida, it would depend on the individual preference of the bride and the bride's family. In fig. 19, the ladies in the photograph have part of their sari draped over as a covering.

It is moreover noteworthy that Muslim women are patronizing photographs and are present in family photographs, as is the case in Hamida's private collection and likewise apparent in the Karimjee Jivanjee personal collections (Oonk, 2004, 2009 and fig. 15).
FIGURE 18

N.V. Parekh's (1923-2007) studio photograph of Hamida Essajee (far left) as part of a group of bridesmaids, from 1940 s PHOTOGRAPH COURTESY OF HAMIDA ESSAJEE'S PRIVATE COLLECTION

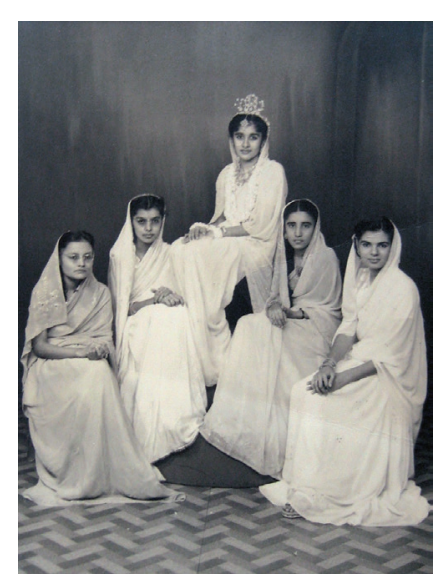

FIGURE 19

In this arrangement, bridesmaids have adopted part of their sari as a head cover.

PHOTOGRAPH BY N.V. PAREKH, FROM 1940S, MOMBASA AND COURTESY OF HAMIDA ESSAJEE'S PRIVATE COLLECTION 
Hamida Essajee and her friends would frequent Parekh's and other modernist studios in Mombasa. They utilized these studios as a social activity and devise creative constructions for their photographs. The conventions of the studio here, are yet extended in the composition of spatial geometry. The costs of these photographs would be divided amongst friends. In the photographs in figs. 18-19, when visiting as part of a group of bridesmaids, the photographs were purchased by the bride's family and each bridesmaid gifted a copy, which is reminiscent of gift exchange and reciprocal function. ${ }^{20}$

Parekh's work and collection of photographs were bought and published by an Italian poet Adriano Sarenco. ${ }^{21}$ Parekh's work drew attention because he principally valued the artistic and theatrical opportunities intrinsic within studio photography. His patrons came from diverse communities including many Muslim communities.

'I thought of himself as an artist in every sense.' Zarina Patel (see Table 1) citing the Italian poet, Adriano Sarenco, while on a visit to Kenya, discussing the monograph he had published on Parekh's work.

Studios hence provide a legacy of communal function. Patrons from Mombasa's manifold communities, are visible in Parekh's archive, including black Kenyans, Arab families, South East Asian Muslims and children and their toys (Sarenco, 2002 and Sheikh-Miller, 2015 pp. 40-1).

Parekh's work has drawn some scholarly interest (Haney, 2010) and his work was exhibited in the 1999 Snap me One exhibition along with photographs by other East African studios, Omar Said Bakor and Likoni Ferry Photos in Kenya. ${ }^{22}$ Haney (2010, pp. 161-2) expands the discussion further to contemporary photographers from the Asian East African diaspora to Europe such as Zarina Bhimji and Allan de Souza. In all cases, the work of these photographers has had prior attention by Western authors or been part of the globalized art circuit.

Parekh's portraiture has been appraised in terms of the glamour allied to Hollywood and the Bombay film industry. ${ }^{23}$ Similarly, the works of modernist photographers Malian, Seydou Keita (1921-2001) and later Samuel Fosse (b. 1962, Central African Republic), resonate with intrinsic fashionable constitution (Haney, 2010, pp. 57-82).

The serendipity of securing Parekh's collection brings an alternative archive to colonial-centred photography - a visual document of diverse patronage that could merely be imagined with respect to the works of Tayabali Hassanali Adamjee.

Patrons visited studios for various reasons, and these have been already documented, to mark rites of passage such as initiation: Accra (Haney, 2010, pp. 58-63), ${ }^{24}$ male circumcision, Zanzibar, during festivals and so on. In conversation with Kenyan Asian photographer Chandoo Vasani (Table 1), whose father founded a photo studio within the premises of a general store in 193os Thika, remarked that during the Second World War, soldiers from European regiments would have their photos taken as a lasting visual record before embarking to the battle front, marking out the institutional and spatial scope of colonizing institutions.

The mutable nature and changeable dispositions of photographs e.g. the Karimjee Jivanjee picture in fig. 16 moreover offer abundant potential to pull out and construe versions of the person. In fig. 20, Noordin Sheikh (right), would visit studios in Nairobi, to mark a sporting achievement and in this instance, a visit to U.N. Patel and Sons was to signify friendship ties with the late Akbar Taherali (in conversation with Noordin Sheikh and late Akbar Taherali - Table 1). The photograph was taken while Noordin was visiting his friend Akbar in Toronto, Canada, who was recovering from a serious illness. The photograph alludes to Pinney's study of photography in India, when some of his subjects would pose with their portraits (Pinney, 1997). 


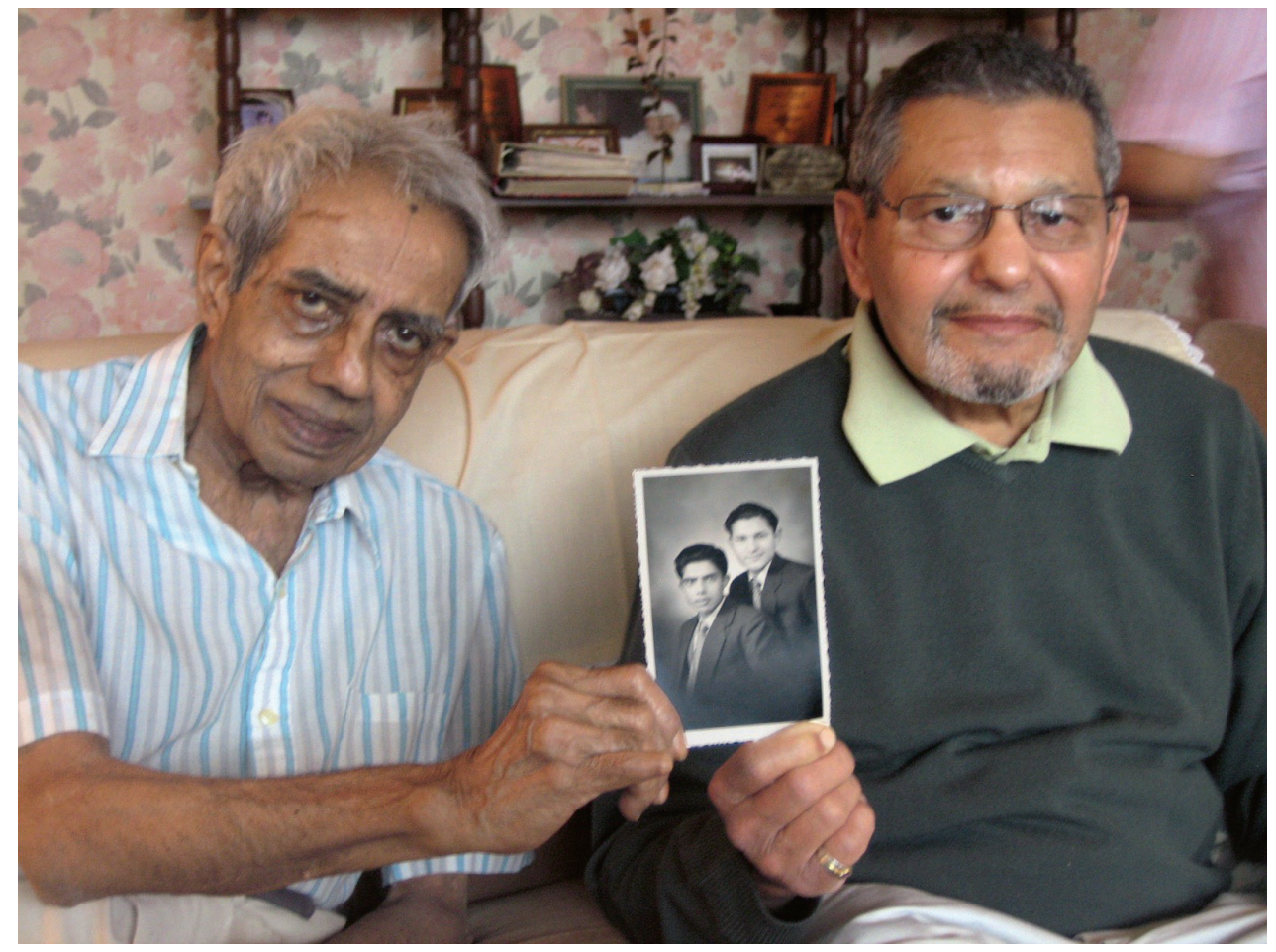

Both friends trace their heritage to the Dawoodi Bohra, Shi'i branch of Islam. Noordin Sheikh's first ancestor, Sheikh Essajee Mulla Bhaijee (fig. 21) settled in Mombasa in the early 1800 s. His family were wealthy landowners from the area of Khambat in India. He was sent on an assignment by the then Sayedna or spiritual leader of the Dawoodi Bohra community, to negotiate a peace between disputing families who had earlier migrated from India to Mombasa.

Sheikh Essajee settled in Mombasa as a merchant trader and banker, supplying anchors to ships. There are various accounts of his honest and generous acts, particularly when assisting families from any background that had lost their main income provider (Salvadori, 1996).

The calotype photograph from the early 1900 s (fig. 21) portrays Sheikh Essajee in the familiar studio setting of a Victorian parlour and toward the latter end of his life. The style of attire of the Sheikh including the cap or topi he is wearing, is unlike the clothing seen and worn by the men in the photographs of the 1920 s and 1930s (figs. 6, 10, 11,15 and 16). The digitized, prolifically copied, indistinct photograph, sits framed in the households of many of his descendants. Fig. 21 sits on an occasional table at the home of Essak Sheikh (father of Asif Sheikh of A24 Media, see Table 1), and a cousin of Noordin Sheikh at his Nairobi home. The reproducibility of a photograph is referenced by Benjamin, earlier (Benjamin, 1999). Here it bears a utility as it changes disposition, affirming and recognizing Sheikh Essajee's tangible existence for his lineages.

\subsection{Painted Photographs}

Also at the home of Essak Sheikh, in one of the family albums, is a painted childhood photograph (fig. 22) of Essak's wife Fehmida Sheikh (mother of Asif Sheikh of A24 Media). In common with others mentioned in this paper, Fehmida's forebears trace their move from India to Mombasa, to seek trading opportunities, eventually settling for the line of glass production. According to Asif Sheikh his mother is aged around
FIGURE 20

Noordin Sheikh (right) was visiting his friend Akbar Taherali in Toronto. The photograph alludes to Pinney's study of photographic studios in India and how his subjects would often pose with their original portraits. PHOTOGRAPH TAKEN BY NASIRA SHEIKH-MILLER, TORONTO, CANADA, 2012

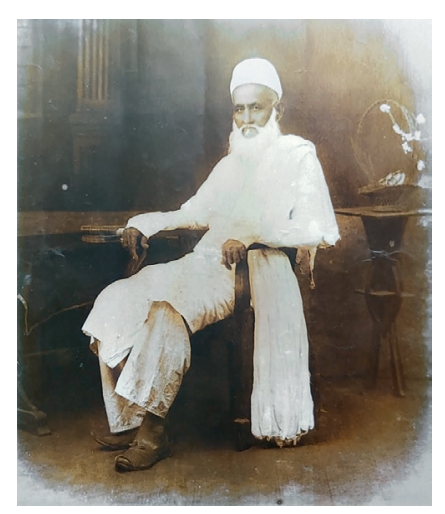

FIGURE 21

Sheikh Essajee Mulla Bhaijee, calotype photograph from early 190os. Memorialized for his integrity, the digitized, prolifically copied image, sits framed in the household of many of his descendants. Photographer unknown

COURTESY OF ASIF SHEIKH'S PRIVATE COLLECTION 


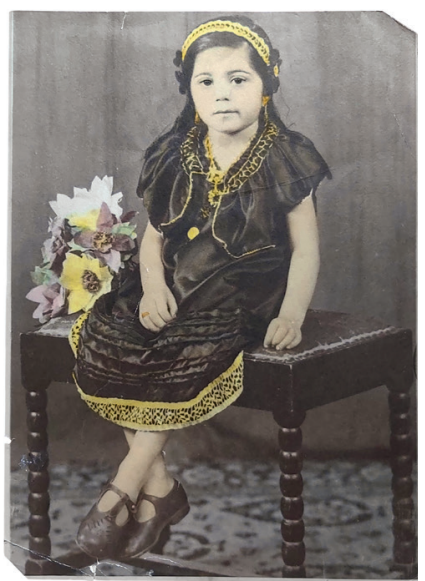

FIGURE 22

Painted studio photograph of Fehmida Sheikh as a child, from 1940s. Photographer unknown, most likely created at one of Mombasa's modernist studios COURTESY OF ASIF SHEIKH'S PRIVATE COLLECTION

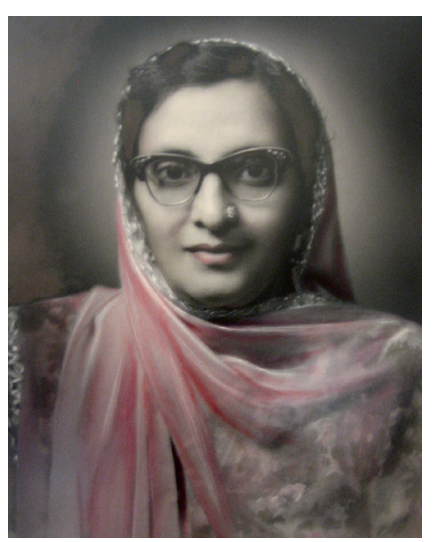

FIGURE 23

The photograph from the 1950's was painted at a studio in Mombasa known for sophisticated painting techniques popularized in India. Photographer unknown COURTESY OF SHIRIN AND SHAMOON ADAMJEE'S PRIVATE COLLECTION three years and the photograph dates to the 1940s. Although, the specific studio is not identified, the modernist photograph is very likely to be taken and painted at one of the Mombasa studios.

Painted photographs were a popular art form in India and similar services were offered by studios in East Africa. The techniques were particularly honed in Mombasa where the shading was more understated than the brightly painted Indian photographs.

At the home of the late female photographer Shirin Adamjee (Table 1), who was also of Dawoodi Bohra background (more discussion about her life in the section - agency and activism), hangs an enlarged painted photographic portrait (fig. 23) of Shirin's mother-in-law, which was created from a small black and white passport photograph (fig. 24) in Mombasa.

An account by photographer Bachu Bhai Patel (Table 1) might illuminate how studios in Mombasa were particularly adept at painting photographs.

In a discussion about the photographer Parekh, Bachu Bhai Patel, recalls that Parekh was working with an artist photographer Surani, before opening the Victory Studio in Mombasa. Surani passed on the techniques of painting photographs to Parekh, together with the pencil technique of eradicating flaws, as well as lightening skin through re-touching.

Fig. 25 is from Anisah Ebrahimjee's family collection of her paternal great grandmother, Fatimabai Sheikh Esmailjee who married the Zanzibari watch merchant Ebrahim Sheikh Esmailjee (see figs. 6 and 11).

Anisah Ebrahimjee's father came across a box of photographs by chance when visiting his parents' original home in Zanzibar and recovered an archive that may have been lost. Similarly, Adriano Sarenco's discovery of the photographer Parekh's archive by coincidence in an attic in Mombasa gives further weight to the susceptibilities of tangible visual heritage to loss.

Within the rediscovered collection, there exists a black and white photograph of which the negative, was most likely the precursor template for the larger painted portrait (fig. 25). It is likely that both the original and painted photographs were produced in a Zanzibar studio. These are older prints than the Mombasa examples dating from the earlier 19oos. The painted photograph is on a textured paper surface and the painting quality heavier than the modernist photographs in figs. 22 and 23.

Furthermore, Pinney's research at the Nagda Studio in India, offers other lines of enquiry within the scholarship thus far slightly explored, if at all. Whether it be theatrical re-touching, the adoption of 'signs of power,' painting photographs; the studio can be a venue 'in which to stage idealized versions of oneself.' (Pinney 1997, pp. 175-86) In the twenty first century epoch of digital media and technological sharing opportunities through platforms such as Instagram, the desire to express ideal forms of the self, where the studio is ubiquitous, is unabated. ${ }^{25}$

\section{7}

\section{Agency and Activism}

\subsection{Women and Photography}

Thusfar in the photographic examples discerned in the collections of Anisah Ebrahimjee, Fatima Sadikot, Hamida Essajee and the late photographer Shirin Adamjee, it is significant that they are all Muslim women who have expressed their first-hand accounts and knowledge about photographs, where both men and women are present, and of photography's art and craft making (Table 1).

However the case studies that have so far been documented have focused on modernist studios that were run and staffed by men. 
Noble Studio was among a group of modernist studios in Nairobi, together with Ramogi Studio (1958-2008) and Gopal Singh's Star Studio (1942-71) that created photographs for everyday clientele.

'My mother had made particular effort, with, her blouse, skirt and matching handbag ensemble, to look as trendy as the trendiest woman of the day.'

Voice of Kenyan writer and actor John Sibi-Okumu above (see Table 1), recalls a childhood studio visit in 1958 with his mother to Noble Studio in Nairobi, to make a portrait of himself and his mother (fig. 26). A journey from rural Kenya to the city was an event, it was also during the Mau Mau resistance. He has additionally contrasted the 'exalted feel good plane' of the studio to photojournalism's recording of 'hatred, violence, calamity and like.'

Studios in Nairobi had a direct or indirect subversive orientation such as the photographing of African nationalist activists in the 1940s and 1950s by both Ramogi and Star Studio.

Also Shirin Adamjee's of Gianni La Magna Studio (1973-2007), at a time very few Asian women were working as photographers. Manjeet Kaur was one of the first Asian women to work as a photographer at Studio One, in the 1960s after being trained by her husband photographer, Kulwant Singh (Rajan and Patel, 2008, pp. 35-9).

I interviewed female photographer, Shirin Adamjee (fig. 2) at her Nairobi home, a few years before she died (Table 1).

Self-taught as a photographer, Shirin's interest in photography started as a child at her father's general store located in a rural area of Korogwe in Tanzania. Her father set up a small studio and processing area within the premises. "The shop was a tiny hut made from corrugated iron. I learned basic negative touching and photograph enhancing skills there.' Akin to Shirin Adamjee, studio photographer and former press photographer, Chandoo Vasani took his early steps into photography when his father Harilal Mohanial Vasani opened a rudimentary studio in Thika at his general store in the Kenyan Highlands, which also served rural communities. Chandoo Vasani described how wedding parties would huddle into their tiny studio at the back of the shop and how he would conscientiously enhance photographs using pencil techniques.

From the mid 1920s onward a number of Asian modernist studios opened in the centre of Nairobi alongside those that were European owned. In Nairobi, on Victoria Street, renamed Tom Mboya Street after Independence, Ram Singh and Sons Photographers opened in 1924, Thakor Bhai Patel (T.L. Patel) who was described as a 'pioneer artist photographer' by later generation photographer, Bachu Bhai Patel, established Anand Studio. Bachu Bhai's father had founded Vanguard Studios in the 193os.

After marriage, Shirin Adamjee moved to Nairobi to join her husband Shamoon (d. 2016) hoping to join a studio based in the city.

By the 196os and 1970s a sizeable number of studios had been established wherein Shirin Adamjee sought employment, however, 'I faced barriers, as studio owners were reluctant to hire a female photographer. I decided, that the only way I would be able to work as a photographer, was to open my own studio.' Shirin went on to purchase Gianni La Magna Studio in 1973, from the previous Italian owner.

A 1985 article about Shirin Adamjee's studio published in Kenya's Daily Nation newspaper (fig. 27) and a feature on the history of Kenyan photographic studios in the quarterly cultural magazine, Awaaz (Zarina Patel and John Sibi-Okumu are also on the editorial team) acknowledge Shirin Adamjee's ground-breaking contribution to photography as a woman in Kenya. ${ }^{26}$

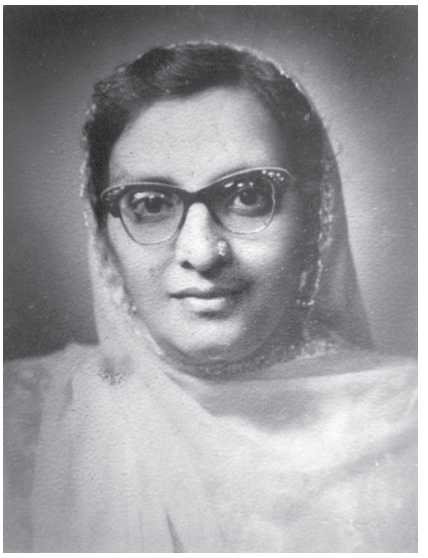

FIGURE 24

The passport photograph to make the painting of Shirin Adamjee's mother in law was kept inside an album at the photographer's home in Nairobi, Kenya. Photographer unknown

COURTESY OF SHIRIN AND SHAMOON ADAMJEE'S PRIVATE COLLECTION

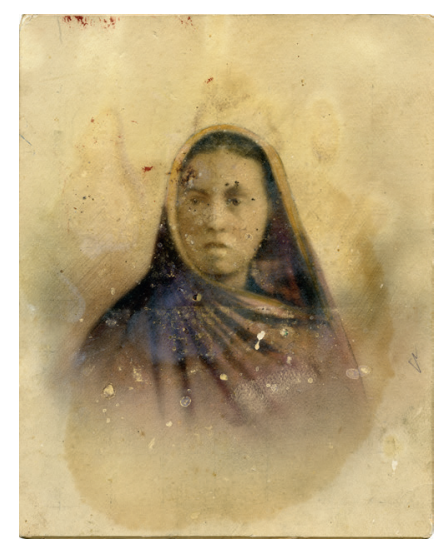

FIGURE 25

Painted photograph of Fatimabai Sheikh Esmailjee from early 190o's, wife of watch merchant Ebrahim Sheikh Esmailjee (figs. 6 and 11). Original photograph and painted versions most likely produced in a Zanzibar studio. The paper has a grainy quality and the painting is heavier than later Mombasa versions. Dimensions: Length $25.2 \mathrm{~cm} \times$ Width $20 \mathrm{~cm}$. Photographer unknown COURTESY OF ANISAH EBRAHIMJEE'S PRIVATE FAMILY COLLECTION 
FIGURE 26

John Sibi-Okumu recalled his Noble Studio visit with his mother from a rural part of Kenya to the capital city in 1958. This was during the Mau Mau uprising and he contrasted 'the feel-good plane' of the studio to the coverage of journalism.

PHOTOGRAPH BY NOBLE STUDIO PHOTOGRAPHER AND COURTESY OF JOHN SIBI-OKUMU'S PRIVATE COLLECTION

FIGURE 27

A press cutting from a 1985 article featuring the photographer Shirin Adamjee, tells the story of her career as one of the female pioneers of photography at her Gianni La Magna Studio in Nairobi. It was kept preserved in a photo album at the photographer's home in Nairobi, Kenya.

COURTESY OF SHIRIN

ADAMJEE'S PRIVATE

COLLECTION
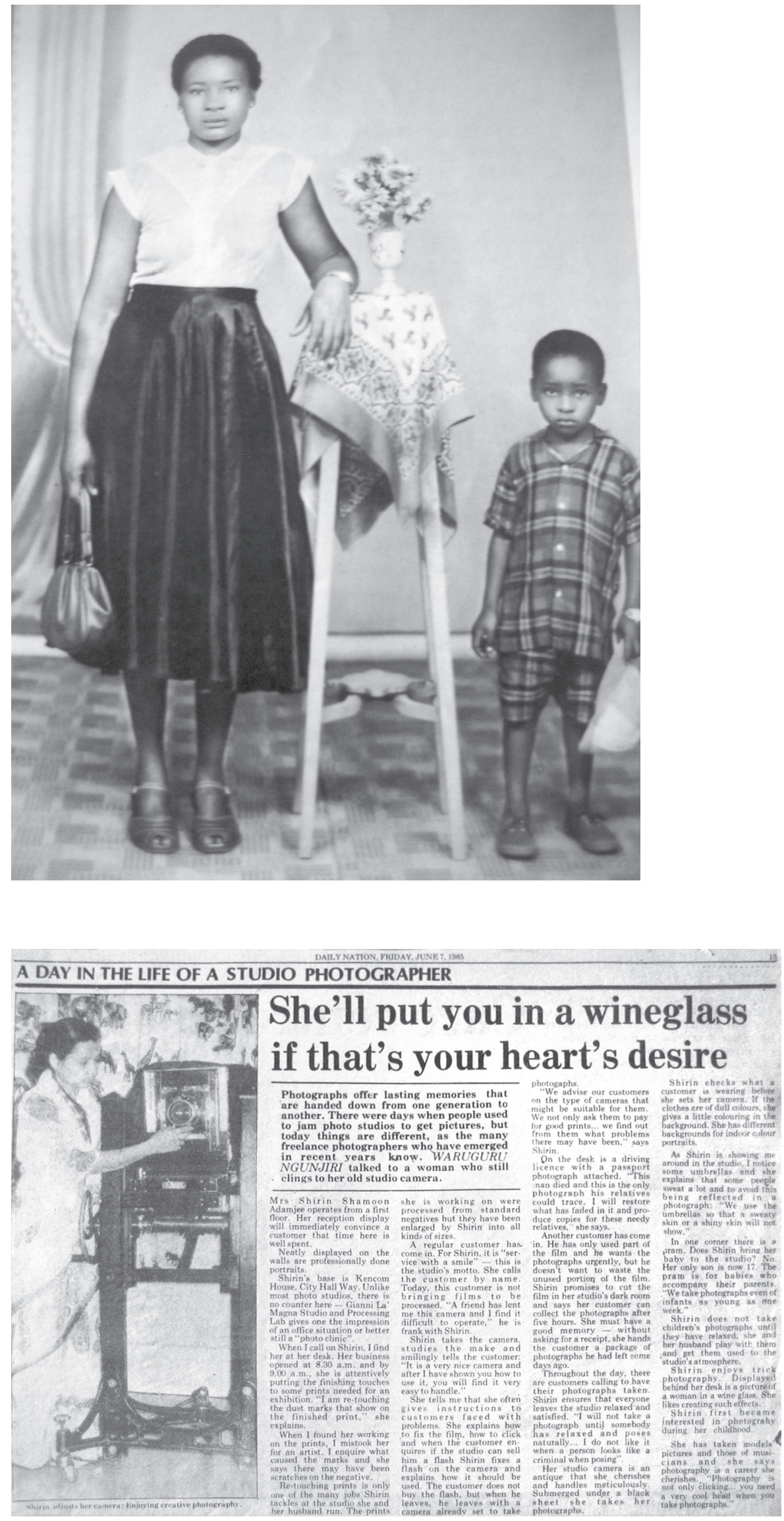
The camera in the news-cutting (fig. 27) was operational when she first acquired the studio and she also spoke about updating equipment with time. She liked to experiment artistically, adopting special effect techniques. Pinney's (1997, pp. 175-86), study of the Nagda Studio and photographic elements in India, investigated the appeal of special effects in photography, among the studio's clientele.

Some of Shirin Adamjee's regular clients included the President Jomo Kenyatta and his family. She recalled taking childhood studio photographs of President Jomo Kenyatta's son, Uhuru Kenyatta who was re-elected as Kenya's President in $2017 .{ }^{27}$

Shirin Adamjee closed her studio in 2007, after the digital revolution in photography changed the nature of the photographic industry. 'I felt I could no longer compete.' She retained some of her portable studio equipment at her home, including her favourite Minolta Camera (fig. 2).

After Shirin Adamjee's death in 2017, all the photographic equipment and remaining negatives and photographs, have been kept in a storage facility. Analogous to previous photographers whose archives have been dispersed after their deaths, there is sound disquiet, that the archive of one of the first female Muslim photographers in Kenya, is in danger of being dispersed and lost.

\subsection{The Intrinsic Activism of Photojournalism}

The direct or indirect activist roles of studios such as Ramogi and Star Studios touched on earlier, extended to launching the career of photojournalists.

\subsubsection{Story of Photojournalist Mohamed (Mo) Amin (1943-96), Kenya} and Tanzania

"No picture is worth your head" was a piece of advice given to me by a press photographer at UPI when I was working in Northern Ireland in the 1970s during the conflict between the Ulster Unionists and the Irish Republicans' in conversation with photojournalist Anil Vidyarthi (see Table 1).

Mo Amin (figs. 3, 5 and 28-34) was a prolific photojournalist of Punjabi Sunni Muslim heritage, and one of the most famed photographers of the region. Many of his films and photographs have reverberated globally and he took exceptional risks in common with other photojournalists, to transmit unique and powerful stories out to the world.28

In 1991 Mo Amin lost his arm covering an assignment in Ethiopia, when he inadvertently encountered an exploding ammunitions dump, following the rebel outing of Mengistu's rule. ${ }^{29}$ In order to continue his career in photography, he re-learned his camera skills using a prosthesis arm (fig. 3 ).

Fig. 3 represents a public resolve to continue his career as a photojournalist with its sizeable stakes. Mo Amin died tragically in a plane crash on a flight from Addis Ababa in 1996, when the plane he was on board was hijacked and dived into the Indian Ocean (Mills and Rayani, 2006, Smith and Amin, 1998).

Though he is the most well-known of the photographers thus far considered within this essay, it is nonetheless important, to document his life and some of his works, in a scholarly piece exploring photography by Muslims in East Africa. The case study of Mo Amin, furthermore provides insights into the role of local photojournalists in the political and historical events of East Africa.

The story began when Mo Amin's father, Sardar Mohamed, undertook a dhow journey on the Indian Ocean from Punjab in India, in 1927 responding to posters advertizing opportunities for work on the Uganda Railway; in Britain's latest crown colony (see fig. 5; and also, section on links between India and East Africa). Sardar Mohamed became part of what has been described as the second wave of migration from India (Gregory, 1993, pp. 9-40; Tetley, 1988). 
FIGURE 28

Mo Amin started his camera career at the school photography club contributing to the

Tanganika Standard and the Tanzanian equivalent of the black consciousness magazine, the Drum.

PHOTOGRAPH BY AN UNKNOWN PHOTOGRAPHER, COURTESY OF SALIM AMIN, CAMERAPIX

FIGURE 29

Nelson Mandela and Winnie

Mandela, his wife at the time, with their fists clenched in a symbol of black power, while on their African Nations tour of 1990 after Nelson Mandela's release from prison

PHOTOGRAPH BY MOHAMED AMIN, COURTESY OF SALIM AMIN, CAMERAPIX
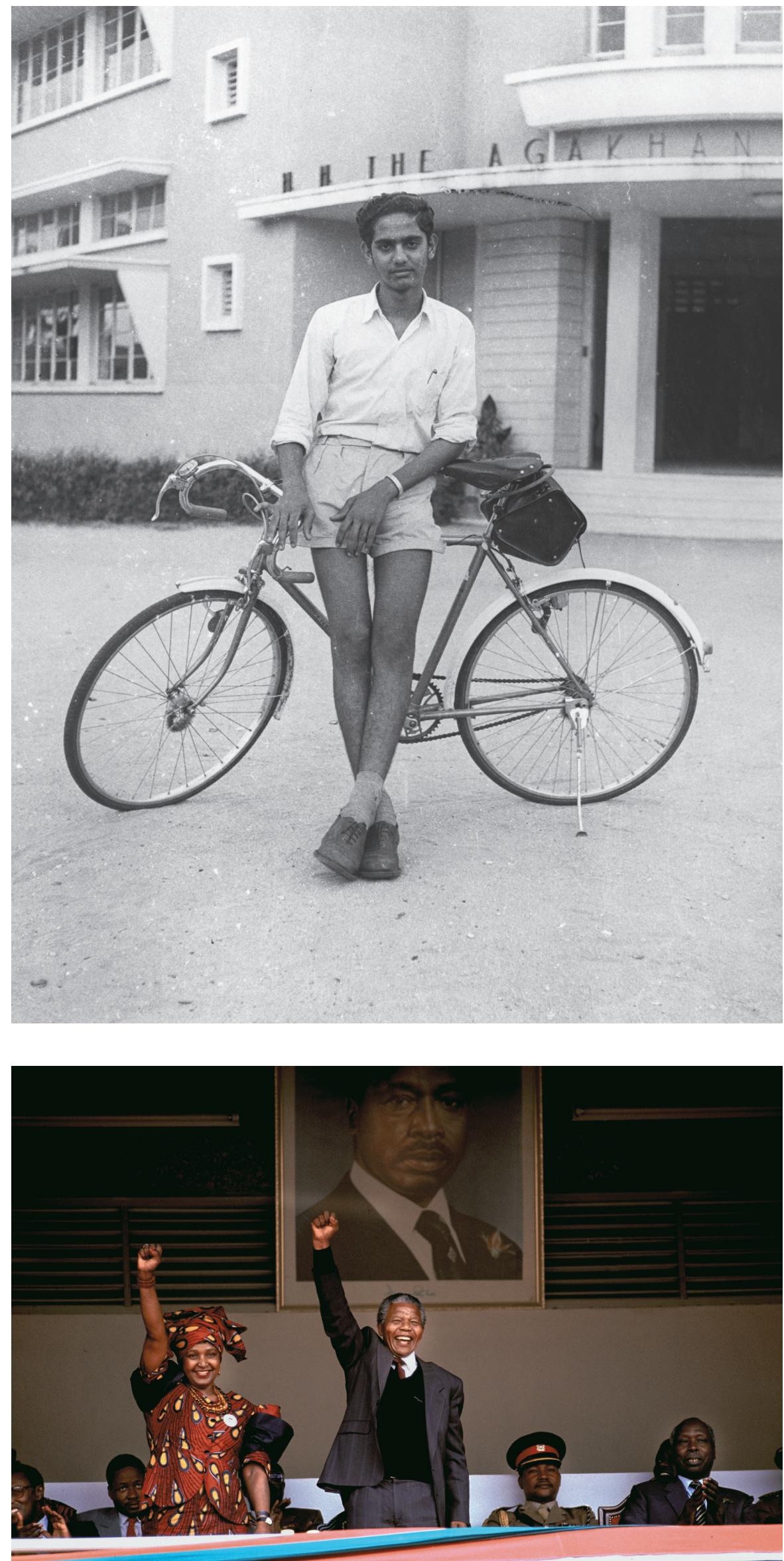


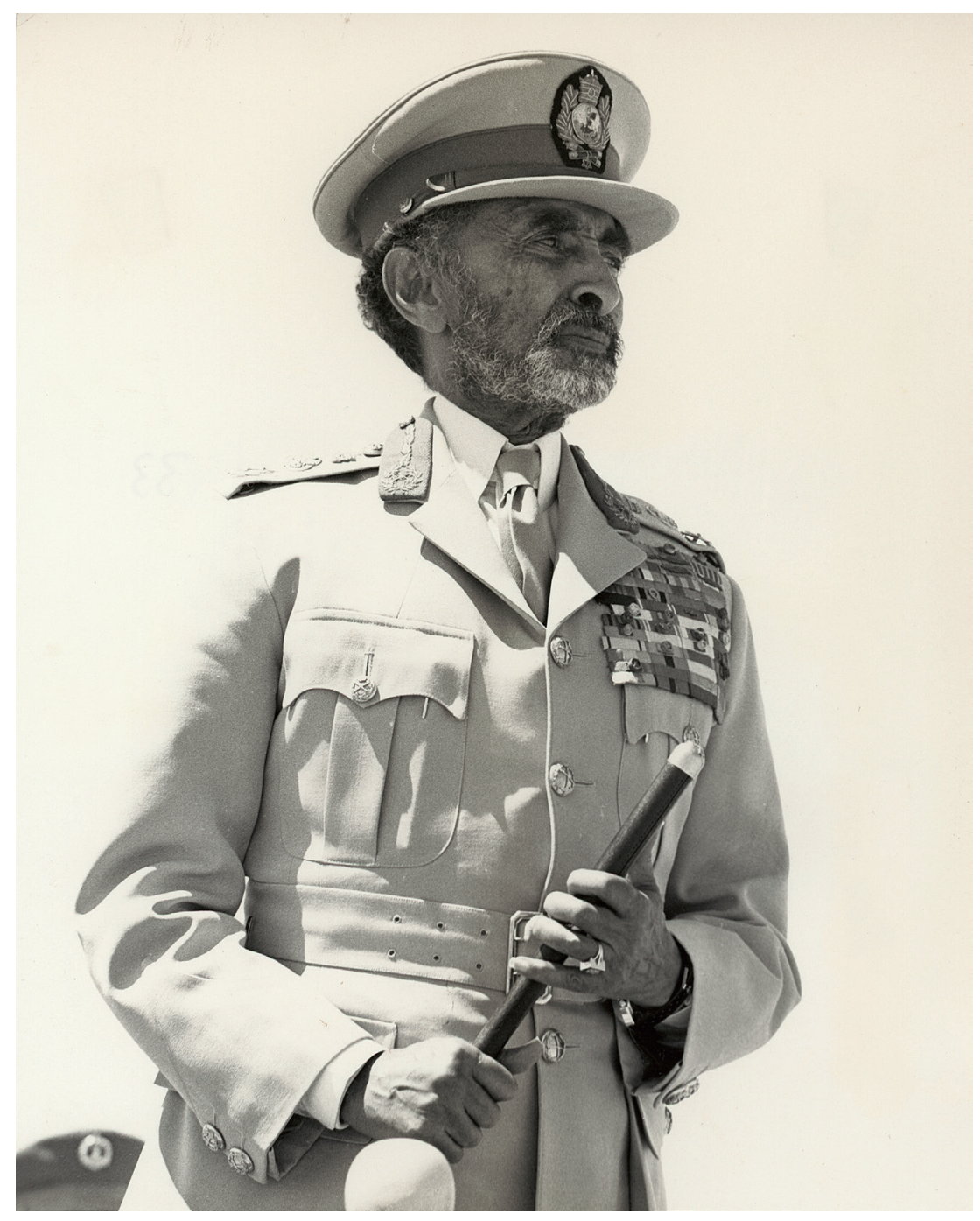

FIGURE 30

Official photograph of Ethiopian Emperor Haile Selassie in Nairobi, from the $1970 \mathrm{~s}$

PHOTOGRAPHER, MO AMIN, COURTESY OF SALIM AMIN, CAMERAPIX

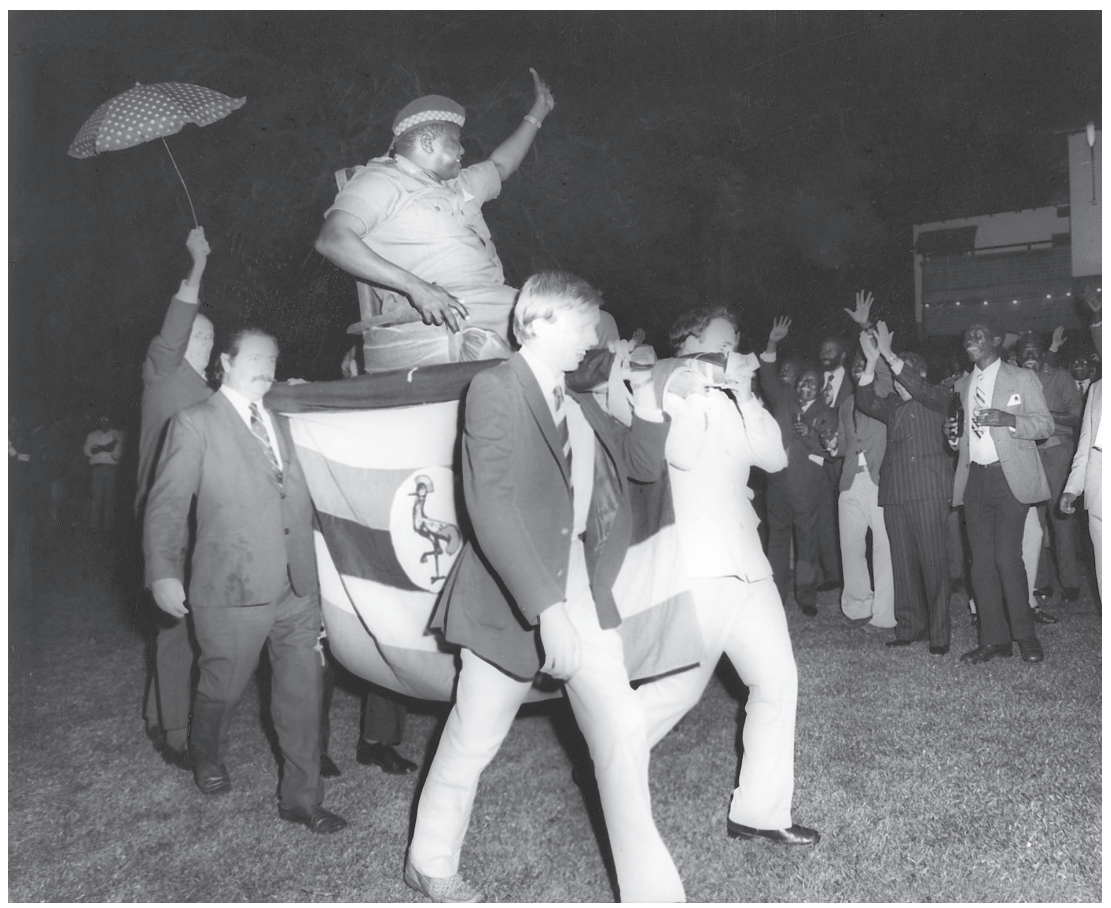

FIGURE 31

This 1970s image of Idi Amin being carried by four white British expatriates created controversy around the world. The photograph taken by Mo Amin in Kampala, Uganda was sent without a by-line.

PHOTOGRAPH COURTESY OF SALIM AMIN, CAMERAPIX 
FIGURE 32

The official photograph at President Kenyatta's inauguration was taken by Mo Amin. This follows the tradition of 'swagger' photography observed in painted and official portraiture.

PHOTOGRAPH, MO AMIN, 1964, NAIROBI, KENYA, COURTESY OF SALIM AMIN, CAMERAPIX

FIGURE 33

Image showing movement of pilgrims as they circumambulate the Kaaba during the Hajj of 1978. Mo Amin was invited by the Saudi government to photograph the Hajj pilgrimage.

PHOTOGRAPH BY MO AMIN COURTESY OF SALIM AMIN, CAMERAPIX
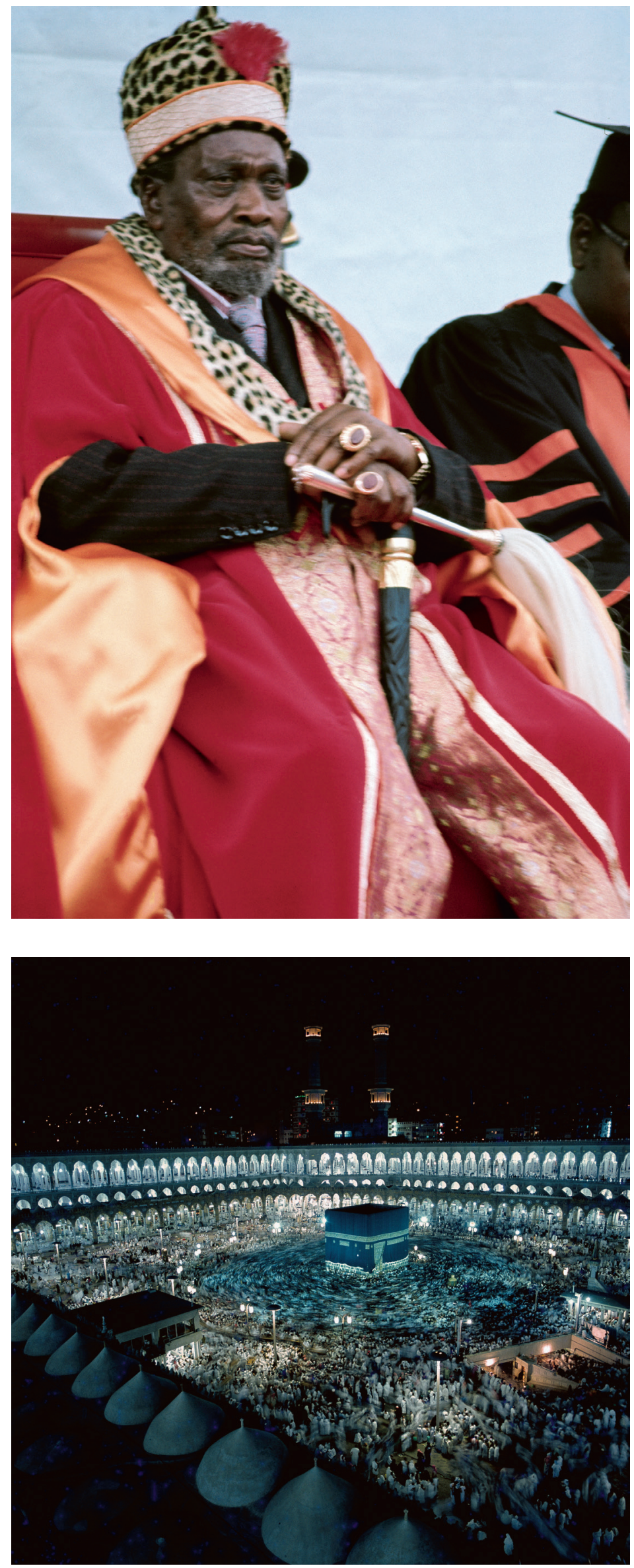


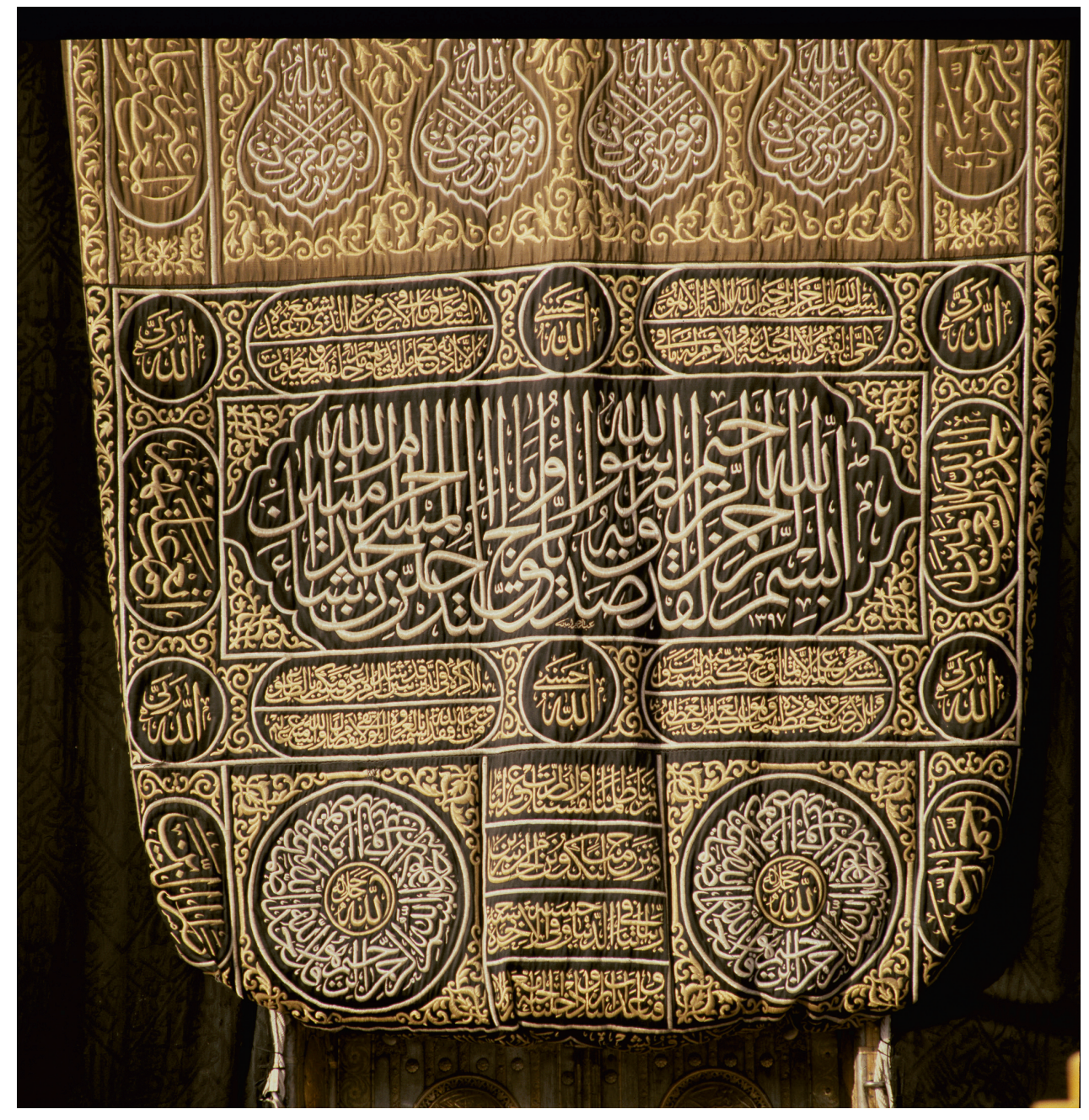

The Uganda railway, nicknamed the Lunatic Express, was to span the Kenyan Coast to Uganda and serve Britain's commercial, military and strategic interests (Smith and Amin, 1998, pp. 39-50). Approved by the British Parliament in the 189os, this controversial and expensive project required 31,983 Indian railway workers to build it between 1896 and 1903 (Miller, 1971, pp. 390-1). After its completion, a workforce was required to maintain and run the lines and hence the migration from India continued.

Cynthia Salvadori interviewed descendants of railway workers, and accounts from their perspectives can be found in We Came in Dhows (Salvadori, 1996). Moreover, Zarina Patel's account of her activist and philanthropic grandfather, A.M. Jeevanjee's responsible dealings with the East African Protectorate Government, supplying workers from Karachi, is an additional perspective on events, which has been overlooked by colonial writers. Patel has also written a biography of trade unionist leader, Makhan Singh (d. 1973). ${ }^{30}$

Sardar Mohamed initially worked as a stone mason building bridges for the Kenya-Uganda Railway in the Rift Valley town of Nakuru, returning to India to marry Azmat Bibi in 1939 (Smith and Amin, 1998, pp. 39-50). Nair has argued that '... the homeland is never actually left behind, but rather extended and attached to regions of social life that extend over space without alienation or stark separation; and because the homeland is not an imagined place of origin, but a living land of family life.' The cyclical link, that Nair refers to, has echoed the experiences of many Asian families. ${ }^{31}$
FIGURE 34

The Kiswah cloth of 1978 draping the Kaaba PHOTOGRAPH BY MO AMIN, COURTESY OF SALIM AMIN, CAMERAPIX 
Eventually, Sardar Mohamed settled with his family in the area of Eastleigh, what was to be the vicinity of the Mau Mau encampment in the 1950s. There is a studio photograph published in Mo Amin's autobiography (Smith and Amin, 1998 pp. 39-50), which has most likely been taken at a modernist studio in River Road in Nairobi. It conforms to the spatial idioms of studio photography (Pinney, 1997 pp. 72-107; Rajan and Patel, 2008-9). There are no women present in the photograph, everyone else is sprucely dressed for the photograph, and Mohammed Sardar is wearing the generic cap often worn by Muslims. Mo Amin's schooling and early photographic career took place in Dar es Salaam after the family was moved to a railway estate there (Smith and Amin, 1998 pp. 39-50).

The Box Brownie camera, bought with money made from selling sweets, was the starting point for developing Mo Amin's photographic skills. Dark room skills, processing and printing were learned at the Aga Khan Indian school through the photographic society (fig. 28). It is likely that this picture was taken by a school friend of Mo Amin and processed at the school's dark room facilities. The photograph seems choreographed with Mo Amin positioned with his early photojournalistic ciphers, a bicycle, and his camera in a satchel, with the school he was reporting for clearly signposted in the background.

While still at school at the age of fifteen, he was contributing to outlets such as the Tanganika Standard and the black consciousness magazine, Drum operated by Sir Tom Hopkinson, former editor of the Picture Post. Its South African counterpart covered activist stories, fashion, music and so on to a black urban audience, amid a staff including black photographers and writers in the face of tightening Apartheid policies (Haney, 2010, pp. 104-8).

Years later as a highly experienced photographer entrepreneur, and through Camerapix a company he set up two years after Tanzania's independence, he would eventually cover South African politics, through its major phases of transformation. From photographing the racist government of Willem Botha in the 1980s to Nelson Mandela (after release from prison) on his African Nations tour in 1990, to the official inauguration of President Nelson Mandela in 1994. Fig. 29 is a photograph taken by Mo Amin of Nelson Mandela and Winnie Mandela, his wife at the time, with their fists clenched in a symbol of black power, from Mandela's African Nations tour (Smith and Amin, 1998).

Mo Amin acted as an agent and a witness for seismic change in the African region, together with his photojournalist compatriots, Priya Ramrakha and Sir Mohinder (Mo) Dhillon, who also traced their heritage to the Punjab. Priya Ramrakha was of Hindu heritage, Mo Dhillon was of Sikh heritage and were likewise connected to the wave of migration through the railways. ${ }^{32}$

Girdhari Lal, photojournalist Anil Vidyarthi's father, who was also the uncle of Priya Ramrakha, was the founder of a printing press in 1933 publishing the Colonial Times newspaper, a subversive bilingual English/Gujarati periodical, created to challenge British rule. "Under the motto "Frank, Free and Fearless" ... it provided a pivotal channel of expression for emerging freedom fighters for instance Tom Mboya and the future President of Kenya, Jomo Kenyatta. 33

Furthermore Girdhari Lal established the publications of Habari Za Dunia the first of its kind in Swahili to be printed independently and the subsequent Luo weekly newspaper, Ramogi. Both were edited by black Kenyans F.M. Ruhinda and Achieng Oneko. These and other papers including the Citizen Times broadcast critiques and raised issues, which the colonial government intended to suppress. The latter was originally founded by a Muslim of Dawoodi Bohra heritage, Noordin Patwa (Vidyarthi, 2002; personally communicated by Noordin Patwa and Pomi Bahal - Table 1). 
Sir Mo Dhillon (Table 1) is a veteran photojournalist now in his eighties, he covered Central African politics and he was also the personal photographer of Emperor Haile Selasse in Ethiopia and Muammar Gaddafi in Libya (Dhillon, 2016). Fig. 30 as it happens is an official photograph of Emperor Haile Selassie, in Kenya, taken by Mo Amin (Smith and Amin, 1998).

In spite of their Asian ethnicity, President Idi Amin of Uganda received both Mo Amin and Sir Mo Dhillon cordially (Dhillon, 2016; Tetley, 1988 p. 117). In 1972 properties owned by Asians and Europeans were nationalized amid the expulsion of 60,000 Asians (Tetley, 1998, pp. 144-46). It is also possible that this was part of a regional trend. The Acquisition of Buildings Act of April 1971 in Tanzania was not targeted at Asians, but nevertheless had a severely detrimental impact on their income. Oonk has written about the impact of the legislation listing former buildings belonging to the Karimjee Jivanjee family (see fig. 16) (Oonk, 20o9, pp. 104-37 and 161-67). There are estimates that 150,000 Asians amounting to $60 \%$ of their population left Tanzania (Oonk, 2009, p. 106).

Mo Amin documented the excesses in Uganda, however these films were wired without a by-line. He also photographed a controversial flamboyant performance of Idi Amin carried on a seat by four white British businessmen, which enraged white expatriates (fig. 31). It was a defiant and crude memorandum to the penetrative legacy of images of the colonial era practise of black labourers carrying the white elite. In one of two merchant travelogues by Dawoodi Bohra merchant Ebrahimji Adamji and Zoroastrian Sorabji Darookhanawala, there is a photograph of a white lady carried by four black attendants (Salvadori 1997).

Ardent rivalry was evident between photojournalists as well as an unremitting pressure to be the first to relay footage of an unseen or unknown event, notwithstanding a congenial rapport between them (Mills and Rayani, 2006; Smith and Amin, 1998; Tetley, 1998; Vidyarthi,2009 and through personal communication with Anil Vidyarthi.)

It is also clear photojournalists worked in a multi-ethnic environment within a local context, as well as competing with and working alongside international foreign correspondents. In interviews with these photographers in 2012, instances of direct and institutional racism were recollected about working conditions at newspapers during the colonial era. 'When I meet the new generation of staff, I would joke with them and say, "do you still have toilets for white, black, and Indian?" There are shocked expressions and then I would tell them the story.', Anil Vidyarthi recalling the period.

Photojournalist Priya Ramrakha discovered parallels between segregation in British East Africa and the Civil Rights struggle during his time in the US. Resonating with Kenyan nationalist leaders, it led to Tom Mboya and Dr Martin Luther King coordinating a programme for eighty-one Kenyan students to attend college in the US (Vidyarthi, 2009).

Priya Ramrakha's photographs of African nationalist leaders, Mau Mau prisoners and the Lari massacre, an atrocity carried out by Mau Mau militants in 1953 (Vidyarthi, 2009 and via personal communication with Noordin Patwa and Pomi Bahal, 2012) relayed according to Landau, the 'only way large numbers of people in Kenya could see what they looked like and what they were experiencing. The Mau Mau did not win independence, it was the national movement' (Landau cited in Vidyarthi, 2009).

As alluded to earlier on, fields of everyday studio photography, intersected with photojournalism. Photojournalists may start their careers as studio photographers or photojournalists often returned to the studio (based on photographer accounts by Anil Vidyarthi, Nazir Sulemanji and Chandoo Vasani - Table 1). 
As referred to earlier, everyday studios engaged in non-conformist activity in the struggle against colonialism. Shantilal Parmar of Ramogi Studio (1958-2008) and Gopal Singh of Star Studio (1942-71) photographed African nationalists in the 1940s and 1950s and their stories or viewpoints would be printed in activist newspapers such as Anil Vidyarthi's father's, the Colonial Times or Noordin Patwa's the Citizen Times.

Mau Mau insurgent, Jomo Kenyatta, who became Kenya's first president, was officially photographed by Mo Amin during the inauguration ceremony in 1964 (fig. 32). Photographs of ensuing presidents have taken on a 'swagger' like, defining tradition, through the adoption of props standing for symbols of power (Pinney, 1997, pp. 72-107). Zimbabwe born artist and photographer, Kidzane Churai has parodied 'swagger' portraiture of African black nationalist leaders in The Black President 2009 photographic artwork series (Sheikh-Miller, 2015, pp. 42-4). ${ }^{34}$

Mo Amin was also a prolific global photographer of wildlife, nature, geography, geology and human experience. He was invited by the Saudi government to photograph the Hajj pilgrimage and to take pictures of the Kaaba within the Masjid al-Haram complex in Mecca (figs. 33 and 34), published in Pilgrimage to Mecca..$^{35}$ These collections of photographs form part of the historical document of the Hajj and related pilgrimage sites. Fig. 33 is one of Mo Amin's highly familiar iconographic images of the Hajj pilgrimage, showing movement of pilgrims as they circumambulate the Kaaba and fig. 34 is the photograph of the Kiswah cloth from 1978.

Photographer Masud Quraishy (see Table 1), has co-authored a chronicle of Punjabi Muslim pioneers of Kenya with Cynthia Salvadori and others. ${ }^{36}$ Quraishy would often join Mo Amin on plane journeys photographing the aerial landscape of Kenya. On the wall in Quraishy's office in Nairobi hangs a large monumental poster of thousands of flamingos, flying over Lake Naivasha, grouped together in a map like shape, resembling the African Continent. He recalls taking this photograph while on a photographic mission with Mo Amin.

Mo Amin received a myriad of honours acknowledging his contribution to journalism, many for the coverage of the 1980 os Ethiopian famine. However a running counternarrative exposes the challenges created by journalists covering African regions through political upheaval and unrest, which leave observers with skewed and stereotypical views of the region (Haney, 2010, pp. 6-12).

Africa 24 Media is a news agency attempting to address this critique. It was originally founded by Mo Amin's son, Salim and a fellow Kenyan, Asif Sheikh as an evolution of the Camerapix company founded by Mo Amin (see Table 1). A recent reorganization has led to a separation of the photographic and film archives. Camerapix is run by Mo Amin's son Salim Amin and A24 Media (fig. 35), which is based at the Karen University campus in Nairobi, is run by Asif Sheikh with a view to training local journalists, emphasizing positive stories from different African countries, moreover, cultivating local talent and promoting community and business development. It has opened YЕво ${ }^{37}$ the first African web-based news portal.

This final section briefly explores the role of social networks supporting the formal arts-based education of photographers with a focus on the Muslim photographer, Nazir Sulemanji (see Table 1) who, comparable to a number of photographers hitherto discussed, is also of Dawoodi Bohra heritage.

Nazir Sulemanji, was a contemporary of photojournalist Mo Amin and attended the same Aga Khan, Indian school for boys in Dar es Salaam. 

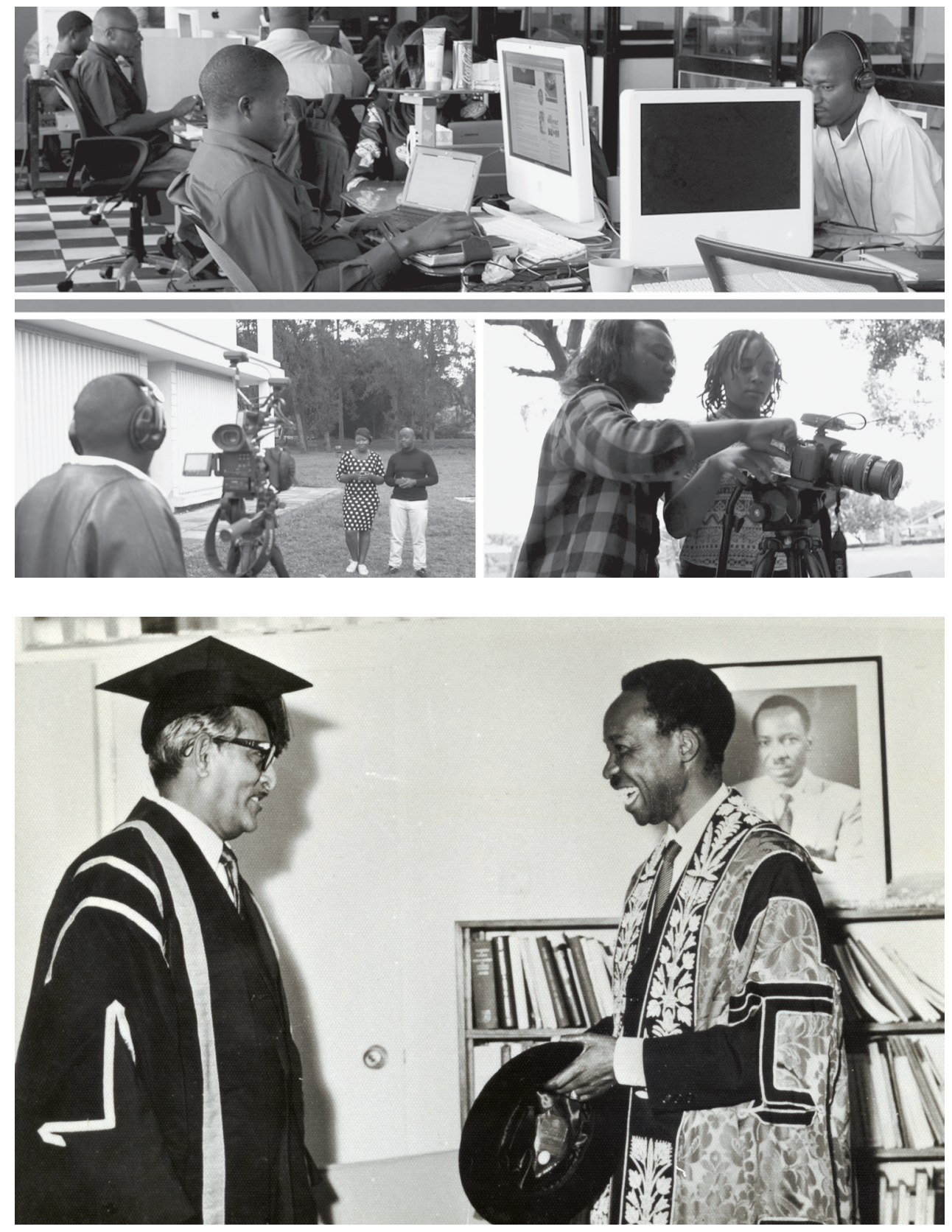

In 1967, Nazir enrolled at the Derby College of Art in the UK to study photography.

In an interview with Nazir he explained his motivations for going abroad. 'Being in Dar es Salaam then, you didn't have full access to information. You only learned about the avenues you could take in photography when you came to a country like England.'

According to Nazir, his grandfather, Gulamhussein Mulla (GM) Sulemanji arrived by dhow, in a similar mode to other emigres from India to Zanzibar, during the earlier era of Indian migration from Gujarat, in the mid nineteenth century to seek trading opportunities. This led to ties with the Karimjee Jivanjee family (a topic of discussion at various intervals throughout this paper), through friendship and communal contact.

Among a number of foundation trusts run by the Karimjee Jivanjee family, was the Education Trust (Oonk, 2009 pp. 127-37). After the death of Sir Yusufali Karimjee, his son, Abdulkarim Karimjee свE (see fig. 36 ), in addition to a number of other official roles, ran the funds dedicated to education. Fig. 36 is a photograph within the Karimjee Jivanjee family collection of Abdulkarim Karimjee with Tanzania's first leader, Julius
FIGURE 35

Africa24 Media, news agency, first evolved from Mo Amin's Camerapix company. Its main mission is to train local journalists and create positive stories from the region.

PHOTOGRAPH BY STAFF PHOTOGRAPHER, NAIROBI, KENYA. COURTESY OF AFRICA24 MEDIA

FIGURE 36

Abdulkarim Karimjee свE with Tanzania's first leader post-independence, Julius Nyerere. At Karimjee Hall, donated by the Karimjee Jivanjee family, which became Tanzania's first parliament building. The photograph from the 196 os by an unknown photographer, conveys informality and warmth between the two men. Dimensions: Length $9 \mathrm{~cm} \times$ Width $13.4 \mathrm{~cm}$ COURTESY OF MATERNAL GREAT NIECE, ANISAH EBRAHIMJEE'S PRIVATE FAMILY COLLECTION 


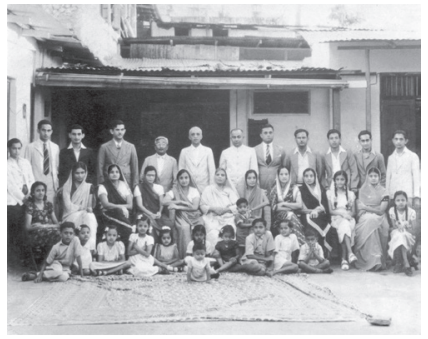

FIGURE 37

The Sulemanji family, photographers Nazir, Muzu and Salim's father, Kassem, stands 3rd from the left. Matriarch Khatijabai Jiwaji the wife of their late forebear Mulla Gullamhussein Sulemanji is seated at the centre. Photograph is from the 1940 . Unknown photographer, possibly a family friend COURTESY OF MUSTAQ ABDULALI'S, PRIVATE COLLECTION

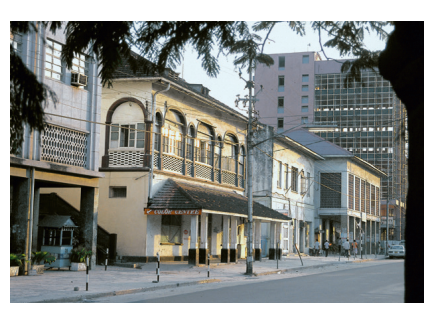

FIGURE 38

Color Centre photographic studio founded in 1972 by photographer Nazir Sulemanji and later developed into a graphics studio and run by brothers Salim and Muzu Sulemanji. Photograph taken by Muzu Sulemanji in 2010, as part of a social architectural project in Dar es salaam PHOTOGRAPH COURTESY OF MUZU SULEMANJI
Nyerere, at Karimjee Hall, which was built by the Karimjee Jivanjee family and donated to public service. It was originally erected as the Town Hall and became Tanzania's parliament building after independence. Fig. 36 is most likely an official photograph that conveys a cordiality between the two men.

Karimjee Jivanjee scholarships were granted ordinarily to students intending to pursue vocational professions such as medicine, law, teaching or accountancy. It was unusual to receive formal funding for arts related courses abroad. There is a contemporary photograph of one of the recipients of the Karimjee Jivanjee scholarships; the late Farida (nee Ebrahim) Sheikh. She was granted a full scholarship to study teaching in the 196 os at the Institute of Education in London. The photograph was taken to celebrate this achievement, she is given a garland of flowers with the whole family in attendance (in conversation with Noordin Sheikh who was married to Farida - Table 1).

In later years, Nazir Sulemanji's photography studies were subsequently funded informally by his late grandfather's business and the Karimjee Jivanjee families based in Zanzibar and Dar es Salaam. Kassem Sulemanji, Nazir's father and uncles (fig. 37), ran the business after GM Sulemanji's death. Fig. 37 is a 1940s Sulemanji family photograph, most likely taken near to their business premises in Dar es Salaam. GM Sulemanji's widow, Khatijabai Jeewaji, is present, sitting as the matriarch of the family at the centre with daughters and daughters in law in the middle row. The printed cloth or jajaam in the foreground of the photograph, is a textile floor covering, often in use, at social gatherings of Dawoodi Bohra families.

Nazir Sulemanji moreover influenced the education and careers of photographers; Anil Vidyarthi (who was also the cousin of prominent photojournalist, Priya Ramrakha (1935-68), who was contracted by Time and Life magazines and tragically killed at the age of thirty-three, covering the Biafran conflict in Nigeria) and Nazir's brothers' Salim and Muzaffar (Muzu) Sulemanji, and his cousin Javed Jafferji (see fig. 4).

On his return to Dar es Salaam, Nazir joined the Daily News as a press photographer, going on to found Color Centre (fig. 38 ) in $1972 .{ }^{38}$ This was initially a photo studio offering processing services that later evolved into a graphics centre. Nazir trained his brothers Salim and Muzu in studio photography skills and the business helped fund Muzu's advanced education in applied arts in Mumbai, India and at the Design School in Basel, Switzerland.

At ease with painting, photography and graphics, Muzu (Table 1) published a photographic book of Dar es Salaam (Sulemanji, 2017) focusing by and large on its existing mix of urban architecture, public and private spaces. Fig. 38 depicts the Color Centre studio, which is housed in the former GM building belonging to the Sulemanji forebear and fig. 39 depicts an urban procession by Dawoodi Bohras marking the salgira (birthday) of their spiritual leader (Sulemanji, 2017, p. 10 and p. 86). Muzu has been using Nikon cameras, Samsung phones and currently the iPhone for photography projects.

Muzu Sulemanji recurrently overlaps photography with fine art, for the main part painting architectural buildings in Zanzibar from photograph prints (fig. 40). Haney (2011, p. 126) has written on the mode of interrelationship, linking painting, printing and photography and how the 'iconicity of a photograph - its tangibility, its portability, its connection to a lived presence - is transmitted into other forms and materials.'

By considering the works and case studies of Asian and Muslim photographers, I have sought to offer counter-narratives and further the analysis of colonial era photography and those beyond elite concerns through private collections. Recording the 
photographic practise of Shirin Adamjee at a time when very few Asian women were working in the industry extends the archive further.

The archives of depicting non-newsworthy events in private worlds of patronage, have offered verisimilitudes and erstwhile viewings of Zanzibar's or Mombasa's communities, distinctly sanctioning debates beyond authenticity and representation pervasive in colonial discourses.

Enwezor and Zaya, however concede that 'yet ironically in attempting to defuse the power of these historicist fictions, we must rely upon photography and its vast array of signs which also stand at the juncture of this refutation (Haney, 2010, pp. 6-12).'

A resolute attempt has been made to document the work of Asian Muslim photographers from colonization to independence and to shed light on the lack of scholarly attention in this area. Political and historical events in Kenya and Tanzania are glimpsed within the confines of photographer experience and their patrons, so too have migratory patterns.

There are moreover areas for further scholarship to engage in. While activism in photojournalism was addressed to a large extent, there are narratives that were not explored fully, such as the direct or indirect subversive orientation of studios. It is furthermore crucial to seek out and conserve archives at the point studios stop operating, due to retirement or death of photographers. There are opportunities for researchers to explore the transition from analogue technologies to digital channels and advocacy.

Links between India, Europe and other parts of the world were fundamental in studio photography and photojournalism and there were interchanges in career trajectories, themes and styles of work. There were varying patterns of skills acquisition. Higher degree courses were sought in Europe or India and self-taught photographers would refer to advanced texts, which were imported from Europe. It was often the case that the early experience of a hobby pursuit would lead to a career in photography. If this led to enterprise, then trade would become a family concern. This was true for studio photographers as well as photojournalists.

By considering the participation and agency of local actors demonstrated by evolving news agencies such as Africa24 Media, greater opportunities exist for scholars to traverse and document East African and continental post-colonial social and activist experience. Accordingly, the options provided by the revolution in digital technology for story-making, anticipate new portals for researchers to enter into.

\section{About the Author}

Nasira Sheikh-Miller was born in Nairobi and moved to the UK as a child. She has worked in several different countries as a senior museum professional, specializing in learning, interpretation and community engagement. This paper developed from her MA in the History of Art \& Archaeology, undertaken at soAs, London.

\section{Acknowledgements}

I would like to thank a number of people based in Kenya, who generously gave of their time and expertise for my project, especially while I was undertaking my research in Nairobi.

For instance, Salim Amin, the CEO of Camerapix and the son of photojournalist Mohamed Amin, who very generously supplied me with a number of iconic images.

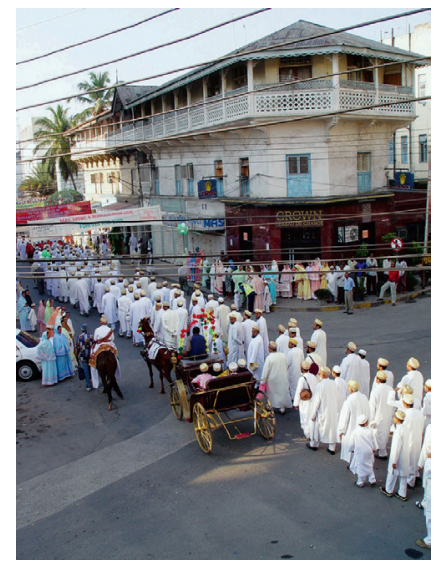

FIGURE 39

Dawoodi Bohra procession marking the salgira or birth of their spiritual leader, in 2010 PHOTOGRAPH BY MUZU SULEMANJI AND COURTESY OF PHOTOGRAPHER MUZU SULEMANJI

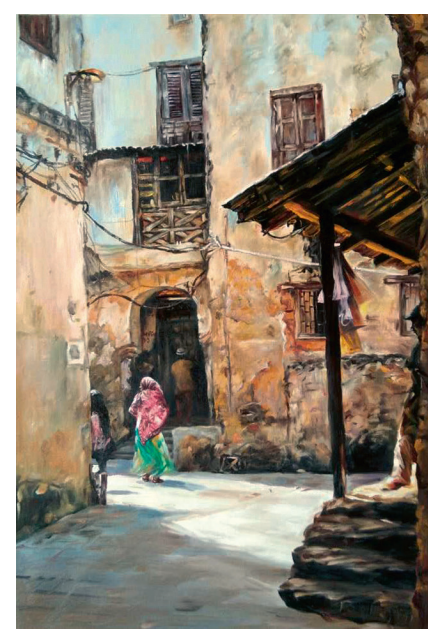

FIGURE 40

Overlapping photography with fine art, Muzu Sulemanji painting of Zanzibar Stone Town (oil on canvas) was completed in 2018 and based on a 2017 photograph taken with a Nikon D81o camera. PHOTOGRAPH COURTESY OF THE PHOTOGRAPHER, MUZU SULEMANJI 
I'd also like to thank Asif Sheikh, Founder and CEO of Africa 24 Media, for his support. He kindly donated photographs from his family's personal archive.

I want to acknowledge the following photographers and photojournalists: the late Shirin Adamjee, Mo Dhillon and Anil Vidyarthi, plus the kind assistance of Zahid Rajan, Zarina Patel and John Sibi Okumu.

Photographers, and their family members, gave me access to cameras, equipment and almanacs of an earlier age, including Bachu Bhai Patel in Nairobi and also Fatima Sadikot in London.

I would like to thank all of my interviewees and family members in East Africa, the UK and Canada for their kind help and support, particularly, Hamida Essajee and Anisah Ebrahimjee who gave me access to their private photographic collections.

I would finally like to thank Dr Charles Gore, supervisor for my MA dissertation, and a considerable support throughout my entire time at soAs.

\section{References}

Adamson, J. (1967). The Peoples of Kenya. London: Collins and Harvill Press.

Amin, Mohamed (1978). Pilgrimage to Mecca. Nairobi: Camerapix.

Attia, Kader (2019). The Museum of Emotion. London: Hayward Publishing.

Behrend, Heike (1998). Narayandas V. Parekh. Translated by N. Ghaddar. In: T. Wendl and

H. Behrend, eds., Snap me one! Studiofotografen in Afrika, London: Prestel, pp. 110-7.

Behrend (1998). Omar Said Bakor. Translated by N. Ghaddar. In: T. Wendl and H. Behrend, eds., Snap me one! Studiofotografen in Afrika, London: Prestel, pp. 118-25.

Behrend (1998). Likoni Ferry-Fotografen. Translated by N. Ghaddar. In: T. Wendl and H. Behrend, eds., Snap me one! Studiofotografen in Afrika, London: Prestel, pp. 126-34.

Benjamin, Walter (1999). Illuminations. London: Pimlico.

Burke, Jason (2017). Kenya Court Upholds President Kenyatta's Election Victory. The Guardian, November 20. https://www.theguardian.com/world/2017/nov/20/kenya-court-upholds-presi dent-kenyatta-election-victory.

Chandan, Amarjit (2008-9). Star Studio 1942-1971. Awaaz 6 (3), pp. 18-23.

Connah, Graham (2001). The edge or the centre: cities of the East African coast and islands. In: African Civilizations: An Archaeological Perspective. Cambridge University Press, pp. 181-222.

Cosslett, Rhiannon L. (2019). Instagram Is Stripping Its Devotees of Its Humanity. The Guardian, March 4. https://www.theguardian.com/commentisfree/2019/mar/o4/instagram-humanity -app-perfect-backdrop.

Delf, George (1963). Asians in East Africa. Oxford University Press.

Dhillon, Sir Mohinder (2016). My Camera, My Life. Dar es Salaam: Mkuki na Nyota Publishers.

Evans, P.C. (2005). The Early Postcards of Zanzibar. East Africa Study Circle.

Garb, Tamar (2011). Figures \& Fictions: Contemporary South African Photography. Gottingen: Steidl.

Ghai, Dharam P., and Yash P., eds. (1970). Portrait of a Minority, Asians in East Africa. Oxford University Press.

Gore, Charles (2007). Art, Performance and Ritual in Benin City (International African Library). Edinburgh University Press.

Gregory, Robert G. (1993). South Asians in East Africa: An Economic and Social History, 1890-1980. Boulder, Colorado: Westview Press.

Haney, Erin (2010). Photography and Africa. London: Reaktion Books.

Hourani, George, and Carswell, John (1995). Arab Seafaring: In the Indian Ocean in Ancient and Early Medieval Times. Princeton University Press. 
Jomard, Edme F., ed. (1809-29). Description de l'Egypte, ou recueil des observations et des recherches qui ont été faites en Egypte pendant l'expédition de l'armée française, publié par ordre de Napoleon le Grand, 23 volumes. Paris: French Government.

Kabir, Nasreen, ed. (1985). Les Stars du Cinema Indien. Paris: Editions du Centre Pompidou/ Centre National de la Cinematographie.

Kirmani, Mubina Hassanali, and Sanaullah (2002). Oral Literature of the Asians in East Africa. Nairobi: East African Educational Publishers.

Landau, Paul S. (2002). Empires of the Visual: Photography and Colonial Administration in Africa. In: Landau, Paul S., and Kaspin, Deborah D., eds., Images and Empires: Visuality in Colonial and Postcolonial Africa. Berkeley: University of California Press, pp. 141-71.

Llewellyn-Jones, Rosie, ed. (2008). Portraits in Princely India 1700-1947. Mumbai: Marg Publications.

Lyne, Robert N. (2006). Zanzibar in Contemporary Times. Zanzibar: Gallery Publications.

Mauss, Marcel (1990). Essai sur le don. Translated by W.D. Halls. London: Routledge. Originally published in 1923 .

Miller, Charles (1972). The Lunatic Express: An Entertainment in Imperialism. London: Macdonald.

Mills, Roger, and Rayani, Murani (2006). Mo \& Me, The Story of Africa's Greatest Photo-Journalist. DVD. Camerapix/Al Jazeera International.

Moore, Tristina (2006). Photos put Zanzibar on the map. BBC Online News, February 14. http:// news.bbc.co.uk/1/hi/world/africa/46986o4.stm.

Nair, Savita (2008). Shops and Stations: Rethinking Power and Privilege in British/Indian East Africa. In: John C. Hawley ed., India in Africa, Africa in India, Indian Ocean Cosmopolitanisms. Bloomington: Indiana University Press, pp. 77-95.

Oonk, Gijsbert (2004). Asians in East Africa, Images: Histories, and Portraits. Arkel, The Netherlands: sca Producties.

Oonk (2009). The Karimjee Jivanjee Family, Merchant Princes of East Africa 180o-200o. Amsterdam University Press/Pallas Publications.

Patel, Zarina (1997). Challenge to Colonialism: The Struggle of Alibhai Mulla Jeevanjee for Equal Rights in Kenya. Kenya: Self-Published.

Patel (2002). Makers of Kenya's History: Alibhai Mulla Jeevanjee. Nairobi: East African Educational Publishers.

Patel (2006). Unquiet: The Life and Times of Makhan Singh. Kenya: Zand Graphics.

Pinney, Christopher. (1997). Camera Indica, The Social Life of Indian Photographs. London: Reaktion Books.

Quraishy, Masud. (2009). List of Exhibitions. Self-Published.

Raheja, Dinesh, and Kothari, Jitendra. (1996). 100 Stars of Indian Cinema. Bombay: India Book House Publishers.

Rajan, Zahid, and Patel, Zarina, eds. (2008-9). Special Issue: Photos and Photographic Memories. Awaaz 6 (3).

Rajan and Patel (2008-9). Parekh \& Co Studio of Yesteryear and Ramogi Studio 1958-2008. Awaaz 6 (3), pp. 12-7.

Rajan, Zahid (20o8-9). Parekh \& Co. Studio 1942-1978. Awaaz 6 (3), pp. 24-30.

Ruete, Emily, Princess Salme of Zanzibar and Oman (1998). Memoirs of an Arabian Princess from Zanzibar. Zanzibar: Gallery publications. Translated from the original German.

Said, Edward W. (2003). Orientalism. London: Penguin Books. Originally published in 1978.

Salvadori, Cynthia (1989). Through Open Doors, A View of Asian Cultures in Kenya. Nairobi: Kenway Publications.

Salvadori (1996). We Came in Dhows, Volumes I-III. Nairobi: Paperchase Kenya.

Salvadori, Cynthia, and Aldrick, Judy, eds. (1997). Two Indian Travellers, East Africa 1902-1905: Being Accounts of Journeys Made by Ebrahimji N. Adamji, a Very Young Bohra Merchant 
from Mombasa \& Sorabji M. Darookhanawala, a Middle-aged Parsi Engineer from Zanzibar. Mombasa: Friends of Fort Jesus.

Salvadori, Cynthia, and Fisher, Shaila Mauladad, and Mauladad, Basheer (2010). Settling in a Strange Land: Stories of Punjabi Muslim Pioneers in Kenya. Nairobi: Park Road Mosque Trust.

Sarenco, Adriano, ed. (2002). N.V. Parekh, An Indian in Mombasa. Verona: Adriano Parise Editore. Serjeant, R.B. (1996). The Fatimi Taiyibi Ismaili Dawah: Ideologies and Community. In: R.B. Serjeant and G. Rex Smith, eds. Society and Trade in South Arabia, London: Taylor \& Francis, pp. 59-77.

Sheikh-Miller, Nasira (2015). From the Studio to the Front-line: The Emergence, Development, and Impact of Asian Photographers in Colonial and Independent East Africa. In: Charles Gore, guest ed., African Arts: African Photography, Autumn 2015, 48, (3), UCLA, pp. 38-47.

Sheriff, Abdul, and Ferguson, Ed, eds. (1991). Zanzibar under Colonial Rule. London: James Currey. Sibi-Okumu, John E. (2008-9). Of Photos and Photographic Memory. Awaaz 6 (3), pp. 8-10.

Sibi-Okumu (2005). Role Play: A Journey into the Kenyan Psyche. Nairobi: Mvule Africa Publishers. Smith, Bob, and Amin, Salim (1998). The Man Who Moved the World: The Life \& Work of Mohamed Amin. Nairobi: Camerapix Publishers International.

Sulemanji, Muzu (2017). Contemporary Dar es Salaam. Dar es Salaam: Mkuki na Nyota Publishers. Originally published in 2010.

Tetley, Brian (1988). Mo, The Story of Mohamed Amin, Front-line Cameraman. London: Moonstone Books.

Vidyarthi, Shravan, director (2007). African Lens: The Story of Priya Ramrakha. DVD. Kenya: Floating Films.

Vidyarthi (2002). Frank, Free \& Fearless, G.L. Vidyarthi: A Pioneer for Kenyan Press Freedom. Awaaz 1 (2), pp. 23-9.

Wendl, Tobias, and Behrend, Heike, eds. (1998). Snap me one! Studiofotografen in Afrika. London: Prestel.

ҮЕво is a factual video on demand platform, focusing on the history, biography and discovery of Africa. Created in (2019) by Africa 24 Media. Based in Nairobi, Kenya: https://yebo.live/en/.

Zanzibar Tourist Task Force/HsP Publications (1994). Zanzibar Guide. London: HsP Publications. Zanzibar History online resource, created (200o) by Torrence Royer. It contains a section on historic Zanzibari photographers, including A.C. Gomes Photo Gallery: http://www.zanzibarhistory.org/Gomes_Gallery.htm.

\section{Notes}

1 Sheikh-Miller, Nasira. (2015). From the Studio to the Front-line: The Emergence, Development, and Impact of Asian Photographers in Colonial and Independent East Africa. In: Charles Gore, guest ed. african arts: African Photography, Autumn 2015, 48, (3), UCLA, pp. 38-47.

2 Haney, Erin. (2010). Photography and Africa. London: Reaktion Books.

3 Pinney, Christopher. (1997). Camera Indica, The Social Life of Indian Photographs. London: Reaktion Books pp. 17-71.

4 Landau, Paul. S. (2002). Empires of the Visual: Photography and Colonial Administration in Africa. In: Landau, Paul S., and Kaspin, Deborah D., eds., Images and Empires: Visuality in Colonial and Postcolonial Africa. Berkeley: University of California Press, p. 141.

5 Adamson, J. (1967). The Peoples of Kenya. London: Collins and Harvill Press.

6 Jomard, Edme F., ed. (1809-29). Description de l'Egypte, ou recueil des observations et des recherches qui ont été faites en Egypte pendant l'expédition de l'armée française, publié par ordre de Napoleon le Grand, 23 volumes. Paris: French Government.

7 Evans, P.C. (2005). The Early Postcards of Zanzibar. East Africa Study Circle.

8 Said, Edward W. (2003). Orientalism. London: Penguin Books. Originally published in 1978.

9 Attia, Kader. (2019). The Museum of Emotion. London: Hayward Publishing.

10 Kirmani, Mubina Hassanali, and Sanaullah. (2002). Oral Literature of the Asians in East Africa. Nairobi: East African Educational Publishers. 
11 Delf, George. (1963). Asians in East Africa. Oxford University Press pp. 1-4; Gregory, Robert G. (1993). South Asians in East Africa: An Economic and Social History, 1890-198o. Boulder, Colorado: Westview Press.

12 Connah, Graham. (2001). The edge or the centre: cities of the East African coast and islands. In: African Civilizations: An Archaeological Perspective. Cambridge University Press, pp. 181-222; Hourani, George, and Carswell, John. (1995). Arab Seafaring: In the Indian Ocean in Ancient and Early Medieval Times. Princeton University Press, pp. 4-5 and pp. 28-36; Oonk, Gijsbert. (2004); Asians in East Africa, Images: Histories, and Portraits. Arkel, The Netherlands: scA Producties, pp. 8-11 and Oonk, Gijsbert. (2009). The Karimjee Jivanjee Family, Merchant Princes of East Africa 180o-20oo. Amsterdam University Press/Pallas Publications. pp. 21-57.

13 Zanzibar Tourist Task Force/HsP Publications. (1994). Zanzibar Guide. London: HsP Publications, p. 12; Moore, Tristina. (2006); Photos put Zanzibar on the map. ввС Online News, February 14. http://news.bbc.co.uk/1/hi/world/africa/46986o4.stm.

14 Salvadori, Cynthia. (1996). We Came in Dhows, Volumes I-III. Nairobi: Paperchase Kenya; Lyne, Robert N. (2006). Zanzibar in Contemporary Times. Zanzibar: Gallery Publications; p. 128, 2006.

15 Miller, Charles. (1972). The Lunatic Express: An Entertainment in Imperialism. London: Macdonald, pp. 390-1.

16 Zanzibar History online resource, created (2000) by Torrence Royer. It contains a section on historic Zanzibari photographers, including A.C. Gomes Photo Gallery: http://www.zanzibarhistory.org/ Gomes_Gallery.htm.

17 Benjamin, Walter. (1999). Illuminations. London: Pimlico.

18 Llewellyn-Jones, Rosie, ed. (2008). Portraits in Princely India 170o-1947. Mumbai: Marg Publications.

19 Serjeant, R.B. (1996). The Fatimi Taiyibi Ismaili Dawah: Ideologies and Community. In: R.B. Serjeant and G. Rex Smith, eds. Society and Trade in South Arabia, London: Taylor \& Francis, pp. 59-77 for further expansion on ideologies and community.

20 Mauss, Marcel. (1990). Essai sur le don. Translated by W.D. Halls. London: Routledge. Originally published in 1923 .

21 Sarenco, Adriano, ed. (2002). N.V. Parekh, An Indian in Mombasa. Verona: Adriano Parise Editore.

22 Behrend, Heike. (1998). Narayandas V. Parekh. Translated by N. Ghaddar. In: T. Wendl and H. Behrend, eds., Snap me one! Studiofotografen in Afrika, London: Prestel, pp. 110-17; Ibid, Omar Said, pp. 118-25; Ibid, Likoni Ferry-Fotografen, pp. 126-34.

23 Raheja, Dinesh, and Kothari, Jitendra. (1996). 100 Stars of Indian Cinema. Bombay: India Book House Publishers; Kabir, Nasreen, ed. (1985). Les Stars du Cinema Indien. Paris: Editions du Centre Pompidou/Centre National de la Cinematographie.

24 Gore, Charles. (2007). Art, Performance and Ritual in Benin City (International African Library). Edinburgh University Press.

25 Cosslett, Rhiannon L. (2019). Instagram Is Stripping Its Devotees of Its Humanity. The Guardian, March 4. https://www.theguardian.com/commentisfree/2019/mar/o4/instagram-humanity-app-per fect-backdrop.

26 Rajan, Zahid, and Patel, Zarina, eds. (2008-9). Special Issue: Photos and Photographic Memories. Awaaz 6 (3).

27 Burke, Jason. (2017). Kenya Court Upholds President Kenyatta's Election Victory. The Guardian, November 20. https://www.theguardian.com/world/2017/nov/2o/kenya-court-upholds-president -kenyatta-election-victory.

28 Tetley, Brian. (1988). Mo, The Story of Mohamed Amin, Front-line Cameraman. London: Moonstone Books.

29 Mills, Roger, and Rayani, Murani. (2006). Mo \& Me, The Story of Africa's Greatest Photo-Journalist. DVD. Camerapix/Al Jazeera International; Smith, Bob, and Amin, Salim. (1998). The Man Who Moved the World: The Life \& Work of Mohamed Amin. Nairobi: Camerapix Publishers International, 1998, pp. 14-38 and 237-44 and Vidyarthi, Shravan, director. (2007). African Lens: The Story of Priya Ramrakha. DVD. Kenya: Floating Films.

30 Patel, Zarina. (1997). Challenge to Colonialism: The Struggle of Alibhai Mulla Jeevanjee for Equal Rights in Kenya. Kenya: Self-Published, pp. 157-99; Patel, Patel, Zarina. (2002). Makers of Kenya's History: Alibhai Mulla Jeevanjee. Nairobi: East African Educational Publishers; and Patel, Zarina. (2006). Unquiet: The Life and Times of Makhan Singh. Kenya: Zand Graphics.

31 Nair, Savita. (2008). Shops and Stations: Rethinking Power and Privilege in British/Indian East Africa. In: John C. Hawley ed., India in Africa, Africa in India, Indian Ocean Cosmopolitanisms. Bloomington: Indiana University Press, pp. 77-95 p. 89.

32 Dhillon, Sir Mohinder. (2016). My Camera, My Life. Dar es Salaam: Mkuki na Nyota Publishers.

33 Vidyarthi, Shravan. (2002). Frank, Free \& Fearless, G.L. Vidyarthi: A Pioneer for Kenyan Press Freedom. Awaaz 1 (2), pp. 23-9. 
34 Also Garb, Tamar. (2011). Figures \& Fictions: Contemporary South African Photography. Gottingen: Steidl, pp. 94-103.

35 Amin, Mohamed. (1978). Pilgrimage to Mecca. Nairobi: Camerapix.

36 Quraishy, Masud. (2009). List of Exhibitions. Salvadori, Cynthia, and Fisher, Shaila Mauladad, and Mauladad, Basheer. (2010). Settling in a Strange Land: Stories of Punjabi Muslim Pioneers in Kenya. Nairobi: Park Road Mosque Trust.

37 ҮЕво is a factual video on demand platform, focusing on the history, biography and discovery of Africa. Created in (2019) by Africa 24 Media. Based in Nairobi, Kenya: https://yebo.live/en/.

38 Sulemanji, Muzu. (2017). Contemporary Dar es Salaam. Dar es Salaam: Mkuki na Nyota Publishers. Originally published in 2010, p. 10. 